Article type : Original Article

\title{
Low resistivity zones at contacts of igneous intrusions emplaced in organic-rich formations and their implications on fluid flow and petroleum systems: A case study in the northern Neuquén Basin, Argentina
}

\author{
J. B. Spacapan ${ }^{1}$, A. D’Odorico ${ }^{2}$, O. Palma ${ }^{3}$, O. Galland ${ }^{4}$, K. Senger ${ }^{5}$, R. Ruiz ${ }^{6}$, R. \\ Manceda ${ }^{7}$, H. A. Leanza ${ }^{8}$ \\ ${ }^{1}$ Y-TEC juan.b.spacapan@ypf.com \\ 2YPF alejandro.dodorico@ypf.com \\ 3 Y-TEC - CONICET octavio.palma@ypftecnologia.com \\ ${ }^{4}$ PGP - The Njord Center - University of Oslo olivier.galland@geo.uio.no \\ 5 UNIS-University centre in Svalbard kim.senger@unis.no \\ 6 Y-TEC remigio.ruiz@ypftecnologia.com \\ 7 Y-TEC rene.e.manceda@set.ypf.com \\ 8 MACN-CONICET hleanza@macn.gov.ar
}

\begin{abstract}
Igneous sills and laccoliths emplaced in sedimentary basins may significantly impact petroleum systems, both positively and negatively. Igneous intrusions provide heat to maturate regionally immature organic-rich host rocks, act as fractured reservoirs hosting commercial accumulations of hydrocarbons, and form structures affecting fluid flow and trapping at different scales. Nevertheless, the petrophysical implications of igneous intrusions on their host rock are poorly known. In this study, we analyse 200 wells in the Río Grande Valley oil field, Neuquén basin, Argentina, where the main reservoirs are in fractured igneous sills. This data set represents a globally unique possibility to characterize the igneous-host rock interaction using both wireline logs

This article has been accepted for publication and undergone full peer review but has not been through the copyediting, typesetting, pagination and proofreading process, which may lead to differences between this version and the Version of Record. Please cite this article as doi: $10.1111 /$ bre. 12363

This article is protected by copyright. All rights reserved.
\end{abstract}


and core material. We identify a systematic Contact Low Resistivity Zone (CLRsZ) at both the upper and lower contacts of the sills emplaced in the organic-rich Vaca Muerta and Agrio Formations. We characterize the nature of these CLRsZ and their petrophysical properties by integrating resistivity and gamma ray well logs, petrographic analyses, petrophysical tests and geochemical analyses. The low resistivity signal of the CLRsZ is dominantly carried by massive-sulphide deposits, mainly pyrite, observed both in the host rock and the chilled margin of the sills. Well log images and porosity-permeability analysis on core plugs show that both the sills and their associated CLRsZ can act as carrier for fluid flow and reservoir for hydrocarbons storage. The thickness of the upper and lower CLRsZ correlate linearly with the thickness of the sill, and the volume of both the upper and lower CLRsZ represents $\sim 40 \%$ with respect to the volume of their associated sill. The thickness of the CLRsZ represents $\sim 13 \%$ of the thickness of contact aureole induced by the sills. In the CLRsZ, a great proportion of kerogen was transformed to hydrocarbon, so that CLRsZ were restricted to the innermost contact aureole of the sills. Our results show that the CLRsZ can have major implications on fluid flow and should be considered in reservoir models in volcanic basins hosting sills emplaced in organic-rich formations.

\section{INTRODUCTION}

Numerous sedimentary basins worldwide host voluminous igneous intrusive complexes, made of dikes, sills and laccoliths, which have tremendous positive and negative impacts on petroleum systems (Rateau et al., 2013; Schofield et al., 2017; Senger et al., 2017; Schofield et al., 2018). When intrusions are emplaced in organic-rich source rock formations, the heat of the intrusions has the potential to considerably enhance maturation of regionally immature source rock formations (Cooper et al., 2007; Fjeldskaar et al., 2008; Monreal et al., 2009; Aarnes et al., 2011; Agirrezabala et al., 2014; Aarnes et al., 2015; Spacapan et al., 2018; Sydnes et al., 2018). Igneous intrusions can themselves act as fractured hydrocarbon reservoirs or hydrocarbon pathways due to pervasive fracturing related to the cooling of the magma (Schiuma, 1994; Orchuela et al., 2003; Bermúdez \& Delpino, 2008; Delpino \& Bermúdez, 2009; Witte et al., 2012; Gudmundsson \& Løtveit, 2014; Spacapan et al., 2018, revised). The emplacement of sills and laccoliths can trigger the uplift of their overburden to form dome structures 
(Hansen \& Cartwright, 2006; Galland, 2012; Magee et al., 2017), which can be efficient hydrocarbon traps often exhibiting 4-way dip closure (Orchuela et al., 2003; Delpino \& Bermúdez, 2009; Schmiedel et al., 2017). Finally, the forceful emplacement of the magma is accommodated by locally intense damage, faulting and folding (Delaney et al., 1986; Mériaux et al., 1999; Senger et al., 2015; Townsend et al., 2015; Spacapan et al., 2017; Zhang et al., 2017).

A key for understanding the implications of igneous intrusions on the evolution of sedimentary basins is to reveal the complex thermo-chemo-mechanical processes at work in the intrusions' contact metamorphic aureoles. It is of relevance to understand the competing mechanisms that either enhance or reduce porosity and permeability. On the one hand, mechanisms enhancing porosity and permeability include the fast maturation of the source rock and boiling of aqueous fluids in the intrusions vicinity. These mechanisms lead to fast fluid pressure build-up, which can result in hydraulic fracturing (Cobbold et al., 1999), and even brecciation, fluidization and hydrothermal venting (Jamtveit et al., 2004; Svensen et al., 2004; Svensen et al., 2007; Schofield et al., 2012; Aarnes et al., 2015; Iyer et al., 2017). Hydrothermal vent complexes associated with the emplacement of Large Igneous Provinces in sedimentary basins released massive amounts of greenhouse or poisonous gases that lead to several mass extinctions during Earth history (Courtillot \& Renne, 2003; Svensen et al., 2004; Polteau et al., 2016). On the other hand, mechanisms reducing porosity and permeability include metamorphic reactions and transformation of sedimentary rocks to hornfel (Senger et al., 2015). Such contact metamorphic reactions led to the deposition of massive ore deposits (e.g., Ganino \& Arndt, 2009; Polozov et al., 2016). Currently, the petrophysical implications of the complex processes within contact metamorphic aureoles on hydrocarbon-bearing igneous complexes are poorly known (e.g. Courtillot \& Renne, 2003; Brune et al., 2017).

In this paper, we present borehole analyses from one of the best-studied petroleum-bearing sill-complexes in the world, i.e. the Río Grande Valley (RGV) oil field, located in the northern Neuquén Basin, Mendoza Province, Argentina (Fig. 1), to assess the petrophysical properties of metamorphic aureoles in contact with igneous sills emplaced in organic-rich shale formations. In the former study, we systematically recognized thin zones of low resistivity between the sill intrusions and the shale host rock in the RGV oil field. These zones will be referred to as Contact Low Resistivity 
Zones (CLRsZ) in this study. Neither the nature and petrophysical properties of these CLRsZ, nor their influence on the nearby igneous reservoirs are known. Similarly, the relationship between the size of the contact aureole and these CLRsZ has not been studied. In this work, we integrate an extensive borehole dataset from the Río Grande Valley oil field in order to characterize various aspects of the CLRsZ, including: (1) regional extent of the CLRsZ and relationship with sill thickness, (2) composition of the CLRsZ, (3) reservoir quality within the CLRsZ, (4) geochemical signatures of the CLRsZ and (5) the potential implications of sill-complexes and CLRsZ in the fluid flow in the sedimentary basin.

\section{GEOLOGICAL SETTING}

The Río Grande valley (RGV) oil field is located in the southern Mendoza Province, between $35^{\circ}-36^{\circ} \mathrm{S}$. It encompasses five main oil fields that are, from north to south, Loma Alta, Los Cavaos, Malal del Medio Río Grande and Los Volcanes (Fig. 1). The valley is a morphologic depression with $\mathrm{N}-\mathrm{S}$ orientation, bounded to the West by the basement-cored anticline of the Sierra Azul - Puntilla del Huincán and to the East by the Palauco, Cara Cura and Reyes ranges (Kozlowski et al., 1993). It is part of the Principal Cordillera and belongs to the southern section of the Malargüe Fold-and-Thrust Belt (Kozlowski et al., 1993; Manceda \& Figueroa, 1995; Horton et al., 2016).

The older rocks cropping out in the area are the volcanic deposits of the Choiyoi Group, exposed in the core of the Sierra Azul anticline, which forms the basement. The evolution of the Neuquén Basin can be summarized in three stages or phases (Vergani et al., 1995; Howell et al., 2005), as follows: (1) rift stage or synrift phase (Late TriassicEarly Jurassic), (2) thermal subsidence stage (sag stage) or postrift phase (upper Jurassic-Early Cretaceous), and (3) foreland stage (Late Cretaceous-Neogene), related to Andean uplift (Fig. 2). The Río Grande Valley basin evolved as an isolated rift basin during Late Triassic and was filled by the synrift deposits of the Precuyano Cycle. During the sag stage, the isolated depocenters coalesced to form a broader basin that was filled by sedimentary deposits of the northern Neuquén Basin in the Mendoza province. The sag stage resulted in the deposition of the Cuyo, Lotena and Mendoza Group. The last one consists of: (1) the Tithonian - Early Valanginian Vaca Muerta Fm. (ca. 125-140 m thick), composed of bituminous shales, deposited under anoxic 
conditions of shelf and slope marine settings, characterized by a high organic matter content (TOC) from 3 to 8\%, with initial hydrogen index of $650 \mathrm{mg} \mathrm{HC} / \mathrm{g}$ TOC and dominant Type II kerogen (Sylwan, 2014; Spacapan et al., 2018); (2) the Middle Valanginian Chachao Fm. (ca 35-50 m thick), deposited above the Vaca Muerta Fm., consisting of a carbonate ramp full of biogenic material (Kozlowski et al., 1993; Brissón \& Veiga, 1998), and (3) the Late Valanginian - Early Barremian Agrio Fm. (ca 250-300 m thick) deposited as a transgressive organic-rich marly shale, with a TOC content from 2 to $3 \%$ and initial hydrogen index of $600 \mathrm{mg} \mathrm{HC} / \mathrm{g}$ TOC. Afterwards, the associated depositional environments became restricted hypersaline marine with deposition of the evaporitic Huitrín Fm. and continental fluvial and lacustrine sediments of the Rayoso Fm. (Vergani et al., 1995). In the Early Cretaceous, the retroarc-sag phase ends and the tectonic regime transitionally changed to compressive, due to a decrease in the subduction angle of the Nazca plate and the beginning of the Andean orogeny (Cobbold \& Rossello, 2003; Ramos et al., 2010). During this time, the inversion of the normal faults within the Triassic rifts and reactivation of older basement faults, led to the formation of the Malargüe Fold and Thrust Belt.

The study area has been affected by two main volcanic episodes (Combina \& Nullo, 2011): the Molle Eruptive Cycle (MEC) emplaced during the Late Oligocene Middle Miocene, and the Huincán Eruptive Cycle (HEC), which occurred during the Late Miocene - Pliocene. These eruptive cycles resulted in thick lava flow sequences, as well as numerous andesitic to basaltic sills dominantly emplaced in the source rock formations of the Mendoza Group (Spacapan et al., 2017; Rabbel et al., 2018). Spacapan et al. (2018) demonstrated that the maturation of the source rock formations in the Río Grande Valley field was dominantly triggered by the heat provided by the sills. In addition, the sills emplaced in the organic-rich formations are the main fractured reservoirs of the hydrocarbon fields along the Río Grande Valley field (Schiuma, 1994; Witte et al., 2012). In this study, we focus on the metamorphic contact zones and their implications for fluid flow and the petroleum system.

This article is protected by copyright. All rights reserved. 


\section{DATA AND METHODS}

Our study integrates the analysis of data from wells distributed in the five producing hydrocarbon fields of the Río Grande Valley area. The data includes (1) 200 well logs, (2) petrographic analyses and core descriptions, (3) porosity and permeability measurements, and mercury injection capillary pressures (See table 1, 2 and 3 in supplementary material), and (4) geochemical data.

\section{Borehole interpretation of Contact Low Resistivity Zones (CLRsZ)}

Borehole data in the Río Grande Valley include 200 wells with resistivity and gamma ray logs (Figs. 2, 3, 4). The logs show that the intrusions detected on borehole data in the Río Grande Valley field are sub-horizontal sills. The Gamma ray (GR) and resistivity (Res) well logs were used to perform systematic measurements of the thickness of the intrusions and their associated upper and lower CLRsZ (Fig. 4). A total of 339 measurements of intrusion and CLRsZ thickness were made. The borehole data allows us to define three distinct facies. (1) The igneous rocks exhibit resistivity values than can range from 5 to as high as $2000 \mathrm{ohm}-\mathrm{m}$ and GR value of 44 API in average. (2) The unaltered host rock has mean resistivity of $42 \mathrm{ohm}-\mathrm{m}$ and GR of $115 \mathrm{API}$. The resistivity logs at distances higher than a few meters from the intrusions exhibit relatively constant behaviour, and indicate the normal, unaltered host rock. (3) The CLRsZ are characterized by low to very low resistivity values ( 0.01 to $5233 \mathrm{ohm}-\mathrm{m}$ ), and a mean GR response of 110 API (Fig. 4).

We define the thickness of these CLRsZ as the distance between the sill's contacts to where the resistivity returns to baseline values typical of the unaltered host rock (Fig. 2). The CLRsZ are systematically observed both at the top and bottom contacts of the intrusions (Fig. 2). This analysis based on geophysical borehole data was crosschecked with, and supported by, cuttings analyses and core descriptions. In addition, 23 wells were used to build a 3D well correlation in the Los Cavaos oil field to determine the lateral extent of the igneous intrusions and their associated CLRsZ (Fig. 3). In total, we identified 339 sill signatures in the wells, and we measured each sill thickness and the thickness of their associated upper and lower CLRsZ (Figs. 4 and 5).

This article is protected by copyright. All rights reserved. 


\section{Petrography and reservoir properties of the CLRsZ}

We performed detailed descriptions of rock samples from five cores sampled in the RGV field. Core 1 is a 10.75-meter-long core sampled at the north of the Los Cavaos field, from the lower contact of a sill located at the middle part of Agrio Fm. at 1970 m (Figs. 1B and 6A, B, C and D). Core 2 sampled a sill emplaced in the Vaca Muerta Fm. from the same well as core 1 (Figs. $1 \mathrm{~B}$ and $6 \mathrm{E}, \mathrm{F}, \mathrm{G}$ and $\mathrm{H}$ ). Core 3 sampled a sill emplaced in the Vaca Muerta Fm, in the Malal del Medio oil field (Figs. 1B and 7). Core 4 is a 10.75meter-long core sampled also at Los Cavaos, but from the Vaca Muerta Fm., at $2570 \mathrm{~m}$ (Figs. 1 and 8). Finally, core 5 is a 9.25-meter-long core from the Malal del Medio oil field and it was sampled at the top of the Agrio Fm., at $2175 \mathrm{~m}$ depth (Fig. 1B and 8).

A complete compositional characterization of the CLRsZ was performed through a detailed analysis of petrographic thin sections from core 1 and core 2 (Fig. 6). Thin section analysis included both polarized and reflected light microscopy to identify bulk mineralogy and opaque compositions (Figs. 6 and 7).

To evaluate fracture distribution in the sills and the CLRsZ, we interpreted a microresistivity (XRMI) and ultrasonic (CASTF) wellbore images logged through the sill sampled in core 3, which was analysed through thin sections to characterize the filling material of the fractures mapped on the images. Open fractures (blue in Fig. 7) are commonly filled with mud. They can be seen as low resistivity-low acoustic amplitude (dark colours) sinusoidal features on images. In contrast, closed fractures (red in Fig. 7) are filled with secondary mineralization or bitumen (Fig. 7) and normally appear as high resistivity-high amplitude sinusoids on images (bright colours), similarly to induced fractures (black in Fig. 7) which are always open and are generated during different stages of drilling. Additionally, laboratory measurements of helium porosity and air permeability (See table 1, 2 and 3 in supplementary material) were performed on cores 1, 4 and 5 to evaluate the reservoir quality of the CLRsZ (Figs. 8 and 9).

\section{Geochemical analyses of the CLRsZ}

Total organic carbon (TOC) values, Rock-Eval pyrolysis and vitrinite reflectance (\%Ro) analyses on cutting samples were obtained from YPF Internal Reports from wells A and B located in the Los Cavaos field (See table 4 and 5 in supplementary material ) (Fig. 10). Samples from well A include cuttings from sills emplaced in the Vaca Muerta Fm.,

This article is protected by copyright. All rights reserved. 
whereas samples from well B contain cuttings from a sill emplaced in the Agrio Fm. Rock-Eval pyrolysis was used to identify the type and maturity of the organic matter, and to evaluate the petroleum potential of the shale host rock (Espitalie et al., 1985; Hunt, 1996). Both the size of the contact aureoles induced by the sills and the petroleum generation potential in the CLRsZ were evaluated using Total Organic Carbon content (TOC) and Rock-Eval pyrolysis parameters such as Hydrogen index (HI) and Transformation Ratio (TR). TOC refers to the total organic carbon content of the rock in weight percent (wt. \%), while the HI is expressed as milligrams of hydrocarbon per gram of the total organic carbon. Furthermore, we calculated the transformation ratio (TR), which is the relationship between original Hydrogen Index (HIO) and actual HI (Waples \& Tobey, 2015). Based on the HI parameter, we defined the thickness of the contact aureole as the distance between the sill's contacts to where the HI returns to baseline values typical of the unaltered host rock (540 to $320 \mathrm{mg} \mathrm{HC} / \mathrm{g}$ TOC approximately). Finally, we obtained three measurements of vitrinite reflectance (\%Ro) for the well B, compiled from YPF internal reports, to evaluate the thermal maturity of the Agrio Fm. (See table 5 in supplementary material). The \%Ro values are mean values of \%Ro and for most of the samples, 1 to 2 measures of \%Ro were performed. The maturity windows used were defined based on Dow (1977). However, the lack of vitrinite particles in the Vaca Muerta Fm. samples does not allow an appropriate interpretation of the extension of the contact aureole associated with intrusions. It is important to note that the contact aureole thickness in the Vaca Muerta Fm. is mainly characterized by Rock-Eval pyrolysis data, instead of vitrinite reflectance.

\section{RESULTS}

\section{Thickness of intrusions and their associated CLRsZ}

The markedly different geophysical signature of the intrusive rocks, the low resistivity zones and the host rocks allows systematic and accurate measurements of thicknesses for the three facies to study their statistical distributions and the relationships between them. 
The measured intrusion thickness varies from 2.3 to $69.5 \mathrm{~m}$, with a mean value of $19.9 \mathrm{~m}$ (Fig. 4B). The thickness histogram exhibits an asymmetric thickness distribution with a peak near $\sim 18 \mathrm{~m}$ and a skewed distribution toward the thicker sills. Such distribution is typical of a Weibull distribution, which has been demonstrated to describe the thickness distribution of igneous dykes (Krumbholz et al., 2014).

The upper CLRsZ thickness ranges from $0.6 \mathrm{~m}$ to $12 \mathrm{~m}$, whereas the lower CLRsZ thickness varies from $0.6 \mathrm{~m}$ to $12.6 \mathrm{~m}$ (Fig. 4C). They also both exhibit a skewed distribution towards the thicker CLRsZ, the peaks being 4-4.5 meters thick.

A plot of the thickness of the upper CLRsZ as a function of sill thickness shows a linear correlation with a significant correlation coefficient $\left(R^{2}\right)$ of 0.720 (Fig. 5A). A similar plot for the thickness of the lower CLRsZ as a function of the thickness of the intrusions yields a linear correlation with a correlation coefficient $\left(\mathrm{R}^{2}\right)$ of 0.725 (Fig. 5B). Most remarkably, Fig. 5C shows an excellent linear correlation between the thickness of the upper CLRsZ and of the lower CLRsZ, with a correlation coefficient $\left(\mathrm{R}^{2}\right)$ of 0.87. Such linear correlations demonstrate a clear link between the intrusion's thickness and the development of the CLRsZ, and the CLRsZ are symmetrical above and below the sills.

\section{Petrographic description}

Petrographic thin sections of the CLRsZ captured in cores 1 (Figs. 6A, B, C and D) and 2 (Figs. 6 E, F, G and H) were analysed in order to identify the mineralogical composition of these zones. Core 1 includes several thin sills and their associated CLRsZs emplaced in the middle part of the Agrio Fm. (Fig. 6A). A petrographic thin section at $1987 \mathrm{~m}$ shows the contact between the sill and the low resistivity contact (Fig. 6B). The margin of the sill is composed of dark fine-grained feldspar, plagioclase, clino-pyroxene, amphibole and biotite, i.e. likely an andesite. The host rock at the sill contact is light grey and is mainly composed of a fine-grained rock matrix made of calcite, quartz and clay minerals, with some fractures completely filled with a mosaic of calcite cement (Fig. 6B). Petrographic analysis of this thin section with reflected light microscope shows the presence of abundant opaque minerals appearing as pyrite aggregates within the sill and the shale host rock near the contact (Figs. 6C and D). On both sides of the contacts, pyrite precipitates are fine-grained aggregates, which consist of euhedral (cubic) grains 
commonly varying in size from of 2.2 to $5 \mu \mathrm{m}$. In some cases, these aggregates can represent up to $15 \%$ of the rock matrix (Figs. $6 \mathrm{C}$ and D).

The Fig. 6E shows a sill from core 2, and its CLRsZ located in the Vaca Muerta Fm. The sill has a porphyritic texture, with plagioclase phenocrysts. The CLRsZ is characterized by a light grey colour and a fine-grained matrix, which hosts clusters of massive sulphide mineralization of more than $3 \mathrm{~cm}$ (Fig. 6F). In addition, some pyrite mineralization occurs as stringers or veinlets cutting through the host rock. The detailed petrographic thin sections analysed with reflected light (Figs. 6H and G) show that massive sulphide mineralization is mainly composed of pyrite aggregates deposited in stratiform bands. Crystals of pyrite are primarily euhedral with dominant cubic forms, varying in size from 1 to $5 \mu \mathrm{m}$ (Figs. $6 \mathrm{H}$ and $\mathrm{G}$ ).

\section{Well images of CLRsZ}

The well log image in Figure 7 displays a sill emplaced in the Vaca Muerta Fm., at $2282 \mathrm{~m}$. This sill is 12 meters thick and the associated upper and lower CLRsZ are approximately 4.2 meters thick. The well log image shows that the fracture intensity is significantly higher in the upper and lower CLRsZ and in the sill than in the normal host rock. In the CLRsZ, fractures generally strike E-W and dip $30^{\circ}$ to $70^{\circ}$, and the mean fracture aperture is $0.84 \mathrm{~mm}$. In the sill, the fractures strike NW-SE and dip from $20^{\circ}$ to $70^{\circ}$ toward the $\mathrm{NE}$, and they have a mean aperture value of $0.55 \mathrm{~mm}$. The petrographic thin section for the CLRsZ shows that fractures are completely filled by bitumen. In contrast, fractures in the sill are filled with two phases of cement: an early zeolite phase precipitated along the walls of the fractures followed by a subsequent calcite phase precipitated in the centre of the fractures (Fig. 7).

\section{Petrophysical characteristics of CLRsZ}

Helium porosity and air permeability laboratory measurements from cores 1, 4 and 5 were used to evaluate the reservoir quality of CLRsZ (Figs. 8 and 9). Mean porosity in core 1, also sampling a sill emplaced in the Agrio Fm., is 5.9\%, and reaches the highest measured porosity value of $14.8 \%$ (Fig. 8). Average permeability is $0.3 \mathrm{mD}$ with a maximum value of $9.08 \mathrm{mD}$. Core 4, sampling a sill emplaced in the Vaca Muerta Fm., is characterized by an average core porosity of $3.13 \%$ and a maximum of $11.4 \%$ (Fig. 8).

This article is protected by copyright. All rights reserved. 
Mean permeability for this core is $0.12 \mathrm{mD}$, while maximum permeability is $0.83 \mathrm{mD}$. Core 5, that sampled a sill emplaced in the Agrio Fm., has a mean porosity of $2.13 \%$ and a maximum value of $3.4 \%$, whereas mean and maximum permeability are $0.2 \mathrm{mD}$ and $5.29 \mathrm{mD}$, respectively (Fig. 8). Most of the porosity values are restricted in the $1.0 \%$ to 5\% range (Fig. 9), with a few samples exhibiting higher values. Permeability values, on the other hand, ranged from $0.01 \mathrm{mD}$ up to $9 \mathrm{mD}$, although most of the measurements are in the 0.01 to $0.1 \mathrm{mD}$ interval (Fig. 9). When plotting the data from the three cores, it can be observed that for the $1.0 \%-4.0 \%$ porosity range, permeability describes a nearly vertical trend, with permeability being almost independent of porosity. Within this interval, there may be an up to two orders of magnitude permeability range for a given porosity value. Samples with porosities higher than $6 \%$ exhibit much less permeability variability (Fig. 9).

\section{Geochemistry of the CLRsZ}

Geochemical profiles were used from two wells (A and B) located in the Malal del Medio oil field to determine the thickness of the contact aureole caused by the thermal impact of the sills (Fig. 10).

Fig. 10 shows two wells (A and B), where the thickness of the sill, the CLRsZ and the contact aureole were measured. Well A intercepts two almost stacked sills in the Vaca Muerta Fm., a 2-meter thick sill and an underlying 14-meter thick sill, with a 4-5-meter thick gap between them (Fig. 10). In well A, there is no significant trend in the TOC values, which vary from $3 \%$ to $6.8 \%$, with an average of $4.12 \%$ (Fig. 10). The values of HI range from 84 to $325 \mathrm{mg} \mathrm{HC} / \mathrm{g}$ TOC and exhibit a systematic decrease toward the sills. The average value of TR is 0.84 , the TR profile exhibiting some increase toward the sill. Based on these data, we consider that the Hydrogen Index is the most reliable proxy to define the shape and thickness of the contact aureole around the sills. This parameter shows that the upper contact aureole is $37 \mathrm{~m}$ thick, while the lower contact aureole is $35 \mathrm{~m}$ approximately (Fig. 10). The CLRsZ in this case has a mean thickness of $4.2 \mathrm{~m}$, a HI value of $84 \mathrm{mg} \mathrm{HC} / \mathrm{g}$ TOC, and a TR value of 0.92 .

This article is protected by copyright. All rights reserved. 
Well B intercepts one 24-meter-thick intrusion in the mid part of the Agrio Fm. The TOC values range from $0.5 \%$ to more $6.2 \%$, with an average value of $1.95 \%$; note that the TOC values increase toward the lower part of the formation (Fig. 10). The values of $\mathrm{HI}$ and TR show the same trends in relation to the sill as seen in the well $\mathrm{A}$. We thus use the same criterion to define an upper contact aureole of $\sim 56 \mathrm{~m}$ in thickness, and a lower contact aureole of $\sim 58 \mathrm{~m}$ in thickness. The upper CLRsZ has a thickness of $9.1 \mathrm{~m}$, an average HI of $27 \mathrm{mg} \mathrm{HC} / \mathrm{g}$ TOC and a TR of 0.95; the lower CLRsZ has a thickness of $8.7 \mathrm{~m}$ and a \%Ro value of $4.82 \%$ (overmature). The \%Ro values significantly decrease above $(0.54 \%$ Ro $)$ and below (0.63\%Ro) the contact aureoles, indicating an early oil window (Fig. 10).

\section{INTERPRETATION AND DISCUSSION}

\section{Thickness correlation between the sills and the CLRsZ}

The observed linear correlations between the thickness of the intrusions and the thicknesses of their upper $\left(\mathrm{R}^{2}=0.70\right)$ and lower $\left(\mathrm{R}^{2}=0.72\right)$ CLRsZs provide evidence that there is a genetic link between the intrusions and their associated CLRsZs. The fact that these CLRsZ are in contact with the sills strongly suggests that they result from contact metamorphism.

Figure $5 \mathrm{~A}$ and $\mathrm{B}$ show that the thickness of the CLRsZ represents approximately $21 \%$ of the thickness of their associated sill. Such linear correlations are similar to results of the thermal numerical models of Annen (2017). These models calculate a maximum temperature profile produced by a host rock away from a sill at any given time after the intrusion. It is thus possible to infer from such profiles the distance from the sill at which a given temperature Tmax was reached, i.e. it corresponds to estimating the position of the Tmax isotherm. The models of Annen (2017) show that the distance between any isotherm and the sill contact increases linearly with the thickness of the sill. We infer from these results that the outer boundary of the CLRsZ marks the position of an isotherm in the contact aureoles of the sills.

The good linear fit of the thickness relation between the lower and the upper CLRsZ (correlation coefficient 0.87), shows that the thermal processes controlling the formation of the CLRsZ are symmetrical on both sides of the intrusions. This is compatible with a dominant heat conduction away from the sills, as shown by the 
models of Aarnes et al. (2010) and Annen (2017). Such symmetry is not compatible with hydrothermal fluid circulation in the host rock induced by the cooling of sills, which are expected to be more prominent upward than downward, leading to asymmetrical thermal imprint (Iyer et al., 2013).

The linear correlation between the thickness of the sills and those of the CLRsZ (Fig. 5) shows that the volumes of the upper and lower CLRsZ represent $\sim 40 \%$ (up to $50 \%$ ) of the volume of the sills they are associated with. If a sill and its associated CLRsZs are reservoirs, such relationships are crucial to establish the total volume and the symmetrical structure of the reservoir.

\section{CLRsZ composition and origin of mineralization}

The analysis of the 200 wells used in this study shows that the CLRsZ are developed only in contact of the sills intruded into an organic rich formation, such as Agrio and Vaca Muerta Fms. When the intrusions are emplaced in sandy sediments (Neuquén Group) or evaporitic units (Huitrín Fm.), no CLRsZ is observed in the resistivity logs (Fig. 2). This shows that the development of the CLRsZ is directly linked to the host rock composition. Svensen and Jamtveit (2010) show that in many sedimentary basins the chemical composition of the sedimentary rock heated by intrusions has a relevant impact on the metamorphic fluid composition. Therefore, the host rock compositions, the type of organic matter, pore fluid composition and water salinity, are the main factors that influence the development of the CLRsZ around the intrusions.

The analysis of core samples and thin sections show the presence of pyritedominated sulphide mineralization in the upper and lower CLRsZ, but also within the chilled margins of the sills (Fig. 6). In some thin sections, pyrite abundance exceeds 15\% of the bulk mineral composition (Fig. 6). Furthermore, other types of sulphurs, such as marcasite and pyrrhotite, have also been reported in the intrusions and their host rock in the RGV (Alberdi-Genolet et al., 2013). Pyrite exhibits excellent electrical conductivity, which is usually comparable to, or even higher than, the conductivity of the formation water. Parasnis (1956) estimated resistivity values for natural pyrite to be in the order of $0.005-5$ ohm-m. (Clavier et al., 1976) measured similar values $(0.03$ to $0.8 \mathrm{ohm}-\mathrm{m}$ ) for the electrical properties of natural and artificial pyrite. They also found that even low pyrite concentrations can reduce substantially the overall resistivity of 
the rock. Thus, the main factor causing the abrupt fall in resistivity can be associated with iron-rich massive sulphide growth in the CLRsZ. Note, however, that the bulk resistivity of the CLRsZ will be controlled not only by the sulphide abundance and distribution, but also by the amount, connectivity and salinity of formation water. The presence of graphite in the CLRsZ, another highly conductive mineral may also contribute to the overall low resistivity in the CLRsZ.

Well correlation across the Los Cavaos oil field shows that pyrite-dominated sulphide mineralization is layer-parallel to sheet-like magmatic intrusions, and the sulphide-layers extend $19.5 \mathrm{~km}$ in north-south direction and $6.4 \mathrm{~km}$ in W-E sense (Fig. 3). Our observations are in good agreement with the interpretations of Corseri et al. (2017), who used the magnetotelluric method to characterize a highly conductive body identified at mid-crustal depth in the north of the Vøring Basin, Norway. They interpreted that the observed anomaly in conductivity is caused by sheet-like, pyrrhotite-dominant deposits along layer-parallel igneous intrusions emplaced in preCretaceous sediments. They also argued that some pyrrhotite deposits can extend several tens of kilometres with thickness up to $45 \mathrm{~m}$. Based on our core observations we proposed that pyrite-dominated sulphide occurs primarily parallel to magmatic intrusions. However, recent work of Pang et al. (2013) and Krivolutskaya et al. (2012) on the world class $\mathrm{Ni}-\mathrm{Cu}$-(PGE) intrusion-associated sulphide deposits of Norilsk, Siberia contain disseminated sulphide mineralization and numerous veins of massive sulphides in the lower parts of the intrusion. In the sampled cores from the RGV field we have not observed sulphide veins inside the sills. However, the lack of such observations could be due to the small size and limited amount of available cores. In the future, more field observations and further core descriptions will be needed to characterize the sulphide composition and distribution within the sills of the RGV.

The presence of massive sulphide deposits in sediments intruded by igneous bodies is usually associated with contact aureoles around intrusions (Antun, 1967; Gillett, 2003; Svensen et al., 2009; Aarnes et al., 2015). This is good agreement with the correlation between the intrusion thickness and the thickness of the associated CLRsZ, which shows that the boundary of the CLRsZ marks an isotherm, which corresponds to the minimum temperature at which sulphides precipitate. Metallic sulphides in contact aureoles have been interpreted in numerous basins worldwide (Zierenberg et al., 1993; Gillett, 2003; Lehmann et al., 2007; Hughes et al., 2016; Corseri et al., 2017). However, 
there might be various mechanisms leading to the formation of sulphide deposits due to contact metamorphism, depending on the geological settings. In the RGV oil field, for example, the host rock is organic-rich shale, whereas the massive sulphide deposits of the famous Norilsk mining district, Siberia, formed by contact metamorphism in evaporitic and carbonate formations (e.g., Pang et al., 2013; Mazurov et al., 2018). Hence, the magma/host rock interactions leading to sulphide deposits in the RVG oil field are likely distinct from those of the Norilsk mining district.

In the RGV oil field, Alberdi-Genolet et al. (2013) argue that the growth of pyritedominated sulphide aggregates in the igneous reservoirs can be associated with different processes, such as: replacement of ferromagnesian minerals by reaction with free $\mathrm{H}_{2} \mathrm{~S}$ (water soluble), cubic pyrite, typically of volcanic origin, pyrite filling secondary pores, indicating that free $\mathrm{H}_{2} \mathrm{~S}$ (water soluble) reacted with soluble iron, framboidal aggregates associated with organic matter that can be interpreted as the precipitation of water-soluble sulphates that were present in sedimentary connate waters after igneous intrusion and fracturing. In addition, Alberdi-Genolet et al. (2013) proposed that $\mathrm{H}_{2} \mathrm{~S}$ in the magmatic fluid reacts with zinc in hydrothermal fluids and iron in ferromagnesian minerals to produce pyrite and marcasite. This mechanism could be the main cause for massive sulphide mineralization in the CLRsZ, when intrusions are emplaced in organic-rich formations.

In the literature, it has been reported that the presence of graphite in the contact aureoles around igneous intrusions can reduce rock resistivity. Rasmussen and Fletcher (2002) described a dolerite sill emplaced in shale in western Australia led to the development of a coarse coke mosaic matrix, indicative of high rates of heating in the contact aureole. Therefore, high conductivity regions of rocks may represent regions of high concentration of graphite. However, in the data available in this work, we did not identify graphite in the CLRsZ, which suggests that the dominant low resistivity signal is carried by pyrite dominant sulphides deposit.

This article is protected by copyright. All rights reserved. 


\section{Reservoir quality of the CLRsZ}

The borehole image analysis shows that the CLRsZ is characterized by high fracture density, similar to that of the sill (Fig. 7). When observed in thin section, these fractures CLRsZ appear to be filled with calcite and bitumen (Figs. 6 and 7). Calcite-filled fractures in the CLRsZ can be related to pressure build-up triggered by the release and expansion of calcium-rich fluids, which eventually result in hydrofracturing and vein growth. Bitumen veins in the CLRsZ (Fig. 7) are first-order evidence of hydrocarbon generation, internal oil migration and expulsion by fracturing resulting from pressure build-up. Similar observations were made by Senger et al. (2015), who concluded that fracture frequency increases in the border of the sill and the hornfel contact zone, such that both zones could be potential pathway for fluid migration. In addition, different types of fracture cement can be observed in the sill and the CLRsZ. the zeolite cement was restricted to cooling joints generated during the sill cooling (Fig. 7), while calcite veins are restricted to CLRsZ and can be related to pressure build-up in the metamorphic contact aureole (Fig. 6B).

The integrated analysis of all the porosity and permeability data from cores 1, 4 and 5 shows that a significant number of samples exhibit reasonable porosity (5 - 14\%) and/or permeability (0.1 - $9 \mathrm{mD}$ ) values, even if many of the samples exhibit low porosity (1 - 5\%) - low permeability (0.01 - $0.1 \mathrm{mD})$. Thus, we infer that the CLRsZ could be considered as fractured reservoir rocks. This conclusion has substantial implications for the reservoir models in the RGV, which have only considered the igneous intrusions thickness without taking into account the CLRsZ as potential reservoir. Knowing that the combined volumes of the upper and lower CLRsZ correspond to nearly $50 \%$ of the volume of the nearby igneous reservoirs, ignoring these zones could lead to severe underestimates of the potential reservoir volume in the RGV.

\section{Relationship between the contact aureole and the CLRsZ}

The borehole data (Fig. 2) only allows the measurement of the thickness of the sills and their associated CLRsZ in the RGV. The geochemical analyses in the wells A and B (Fig. 10) enables their comparison to the thickness of the contact aureoles created by the intrusion and the thickness of the sill and their CLRsZ. Fig. 10 shows that a 14-m thick sill develops a contact aureole of $35 \mathrm{~m}$ on average, while the CLRsZ has a mean 
thickness of $4.2 \mathrm{~m}$. This suggests that the thickness of the contact aureoles in the RGV is about twice as thick as the sill, whereas the CLRsZ represents only $11 \%$ of the contact aureole. The CLRsZs mapped in this study thus account for only a small part of the thermal impact of the sills on the host rock. Our measurement imply that the volume of the matured source rock is much larger than that of the CLRsZ. Futhermore, the TR values in the CLRsZ have a mean value of 0.93 and a mean HI of $30.6 \mathrm{mg} \mathrm{HC} / \mathrm{g}$ TOC (Fig. 10 ), and values of vitrinite reflectance in the well B and another presented by Spacapan et al. (2018) show that the CLRsZ experienced dry gas-overmature windows. This suggests that great proportion of kerogen was transformed to hydrocarbons and that most of the samples in the CLRsZ are largely barren (Fig. 10).

We discussed above that the boundary between the CLRsZ and the unaltered host rock might mark the position of an isotherm within of the contact aureoles, the temperature of which is not constrained. Aarnes et al. (2010) split the contact aureole in an outer and inner aureole based on a threshold value of vitrinite reflectance. The outer aureole is defined by \% Ro $>0.5$, where wet gas and potentially oil can be generated, whereas the inner aureole is defined by vitrinite reflectance \%Ro $>1.5$ where only dry gas is generated. Our vitrinite reflectance data from well $B$, showing dry-gas to overmature source rock, suggest that the CLRsZ even represent the hottest part of the inner aureole of Aarnes et al. (2010). More detailed work is necessary to constrain the exact origin of the boundary of the CLRsZ in the RGV.

\section{IMPLICATIONS OF THE SILLS-CLRsZ ON HYDROCARBON MIGRATION}

\section{AND STORAGE IN SEDIMENTARY BASINS}

Based on the data presented in this study, we propose a conceptual model that summarizes the potential implications of sills-complexes and their associated CLRsZ on the petroleum system in the RGV.

Fig. 11 summarizes our main results based on geochemical, petrophysical and thin section observations. The geochemical data and the thin sections observations show that the low resistivity of the CLRsZ is caused by the pyrite mineralization in both the chilled margins of the sills and the innermost part of the contact aureole, which 
experienced dry gas-overmature window (Fig. 11). The sills and their associated CLRsZ exhibit high fracture intensity and good porosity-permeability quality to transport and store hydrocarbon. Therefore, we defined both zones as carrier and reservoir (Fig. 11). In contrast, in the rest of the contact aureole (outer part of the inner aureole and the outer aureole), the porosity-permeability condition and fracture density tend to decrease, while the unaltered host rock could act as a seal for hydrocarbon flow. We infer from our observations that the low resistivity of the CLRsZ is dominantly carried by massive pyrite aggregates (see schematic profile of Fig. 11). However, the presence of solid organic matter, as pyrobitumen or graphite, can be other causes that contribute to the observed decrease in resistivity (Fig. 11).

Our results show that the thermomechanical processes in the CLRsZ enhances fracturing of the host rock, which can have significant effects on fluid flow and storage in the contact aureoles. These effects can be additional to the intrusion's damage zones, which are defined as local areas of concentrated fracturing, faulting and damage induced by the emplacement of the intrusions (Delaney et al., 1986; Mériaux et al., 1999; Abdelmalak et al., 2012; Spacapan et al., 2017; Zhang et al., 2017). Such damage zones are purely mechanical and occur in any type of host rock lithology, such as limestone, sandstone, shale, etc. This implies that shallow intrusions emplaced in the sandstones of the Neuquén Group can generate a mechanical damage zone, even in the absence of a CLRsZ (Fig. 2). In contrast, the massive sulphide aggregates and solid organic matter concentration in veins documented in the CLRsZ show that the occurrence of thermomechanical processes in the CLRsZ strongly depends on the composition of the host rock, and occurs only in organic-rich shale. Thus, the intrusions emplaced in the Vaca Muerta and Agrio source rocks can lead to both mechanical damage zone and fracturing as a result of the thermomechanical processes in the CLRsZ, with the potential to considerably enhancing local permeability in the vicinity of igneous intrusions (Monreal et al., 2009; Spacapan et al., 2018).

As discussed above, individual intrusions and their associated CLRsZ and damage zones can have major implications on the heat flow and migration pathways of fluids (Cartwright et al., 2007; Senger et al., 2015; Zhang et al., 2017). Based on regional well correlations (Fig. 3) and the field observation performed by Spacapan et al. (2017) 
we suggest a potential architecture for the sill-complex in the RGV as composed by interconnected network of sills, inclined sheets and dykes (Fig. 12). In addition, the lateral extensions of the sill-complexes is approximately $7.5 \mathrm{Km}$ (Fig. 3B), representing a $37.5 \%$ of the structural section of the Los Cavaos oil field (Fig. 12, rectangle A). Such interconnected network of high-permeability pathways can thus have significant effects on the regional hydrocarbon migration and storage. We infer from our results that part of the hydrocarbons generated in the intrusions' contact aureoles can accumulate in sillCLRsZ reservoirs, as these are sealed by the surrounding, low permeability host rock. Conversely, inclined sheets and vertical dikes can act as conduits promoting hydrocarbon transport and storage in shallower formations (Fig. 12). They are difficult to interpret in seismic lines and borehole data due to their vertical distribution. Dikes were considered to be the main feeders of sills, but recent works show that sills fed by inclined sheets from other sills are more common than thought before (Hansen \& Cartwright, 2006; Cartwright et al., 2007; Muirhead et al., 2012; Galland et al., 2018) Intrusions such as dikes and inclined sheets could destroy the cap rock, promoting hydrocarbon leakage or can act as channels for hydrocarbon migrations, promoting petroleum accumulation in shallow intrusions located in the Neuquén Group. Therefore, the degree of connectivity between the individual intrusions and their associated CLRsZ is a highly relevant aspect in fluid migration, since it can increase the fluid flow through the basin, connecting deep source rocks with shallow reservoirs (Fig. 12). The importance of intrusions and CLRsZ on vertical hydrocarbon migration and storage could have a relevant impact in future projects related to the hydrocarbon exploration in shallow sills located in the Neuquén group.

Note that in the RGV oil field, and in the Neuquén Basin in general, we do not observe any hydrothermal vent complex like those widely documented in, e.g. the Karoo Basin, South Africa, offshore Norway, and Siberia (Svensen et al., 2004; Ganino \& Arndt, 2009). This implies that the emplacement of the igneous complexes in the Neuquén basin did not trigger catastrophic fluid flow that connected the subsurface source rocks to the atmosphere. This indicates that the pressure build-up generated by hydrocarbon maturation in the RVG oil field was not high enough to fragment and fluidize the overburden. We infer that the hydrocarbons produced in the thermal aureoles of the igneous complexes remained trapped in the subsurface and migrated at a much slower 
speed than through hydrothermal vent complexes. However, due to the short time scales of cooling of igneous intrusions, the migration of hydrocarbons was likely much faster than hydrocarbons produced from conventional burial of organic-rich formations. The transition controlling whether a basin "opens", i.e. releases fluids through hydrothermal vent complexes, or remains "closed" remains to be constrained.

\section{CONCLUSIONS}

In this study, we investigated the nature of low resistivity zones identified at contacts of sill intrusions emplaced in organic-rich shale formations, and we address their implications for fluid flow and petroleum systems. To do so, we integrate borehole data from 200 wells, and petrological and petrophysical analyses from cores sampled from five oil fields in the Río Grande Valley field, northern Neuquén Basin, Mendoza province, Argentina. In these fields, the main hydrocarbon reservoirs are fractured igneous sills. The conclusions of our study are the following.

1. Only sills located in organic-rich formations, i.e. Agrio and Vaca Muerta Fms, exhibit Contact Low Resistivity Zones (CLRsZ) (0.01 to 5ohm-m) at both the lower and upper contacts of the sills with the host rock.

2. We measured the thickness of the sills and their associated CLRsZ in 200 wells in the RGV field and show that the thickness of both the lower and upper CLRsZ correlated linearly with the sill thickness; the CLRsZ represents approximately $21 \%$ of the sill thickness. The upper and lower CLRsZ are linearly correlated, showing that they develop symmetrically on both contacts of the sills.

3. The low resistivity signal of the CLRsZ is dominantly carried by massive sulphide deposits, mainly pyrite. Sulphide mineralization was mainly observed in the host rock contact and in the chilled margins of the sills, therefore both zones compose the CLRsZ. In addition, even if the presence of graphite in the CLRsZ was not documented, it can be another cause that contributes to the low resistivity.

4. CLRsZ are layer-parallel to magmatic sheet intrusions. Well correlation shows that the CLRsZ have a similar lateral extent than those of the studied sillcomplex. In the Los Cavaos oil field, for instance, the CLRsZ and the sills extend $19.5 \mathrm{~km}$ in north- south direction and $6.4 \mathrm{~km}$ in W-E sense

This article is protected by copyright. All rights reserved. 
5. Well log image and porosity-permeability plugs show that both the sill and the CLRsZ can act as carrier and reservoir for hydrocarbons. Ignoring the thickness of the upper and lower CLRsZ can lead to significant underestimates of the reservoir volume and its capacity for fluid transport and storage.

6. The thickness of the contact aureoles is twice that of sills thickness, and the CLRsZ represent $\sim 11 \%$ only of the contact aureole thickness. TR and HI data from CLRsZ show that great proportion of kerogen was transformed to hydrocarbon (Dry gas- over mature window). The CLRsZ thus corresponds to the very inner part of the contact aureole induced by the sills.

\section{Acknowledgements}

The authors are grateful to YPF for funding the fieldwork and providing subsurface data. We thank Ignacio Brisson (YPF), Martin Fasola (YPF) and Raul De Barrio (UNLP) for exchanging important ideas and discussions. We also thank Y-TEC for borrowing the laboratories to perform the petrographic description. Finally, we thanks to the two anonymous reviewers and Sverre Planke for their inspirational revisions.

\section{REFERENCES}

Aarnes, I., SVensen, H., Connolly, J.A. \& PodladChikov, Y.Y. (2010) How Contact Metamorphism Can Trigger Global Climate Changes: Modeling Gas Generation around Igneous Sills in Sedimentary Basins. Geochimica et Cosmochimica Acta, 74, 7179-7195.

Aarnes, I., SVensen, H., Polteau, S. \& Planke, S. (2011) Contact Metamorphic Devolatilization of Shales in the Karoo Basin, South Africa, and the Effects of Multiple Sill Intrusions. Chemical Geology, 281, 181-194.

Aarnes, I., Planke, S., TrulsVik, M. \& SVEnSEN, H. (2015) Contact Metamorphism and Thermogenic Gas Generation in the Vøring and Møre Basins, Offshore Norway, During the Paleocene-Eocene Thermal Maximum. Journal of the Geological Society, 172, 588-598.

Abdelmalak, M.M., Mourgues, R., Galland, O. \& Bureau, D. (2012) Fracture Mode Analysis and Related Surface Deformation During Dyke Intrusion: Results from 2d Experimental Modelling. Earth and Planetary Science Letters, 359, 93-105.

AgirRezabala, L.M., Permanyer, A., SuÁrez-Ruiz, I. \& Dorronsoro, C. (2014) Contact Metamorphism of Organic-Rich Mudstones and Carbon Release around a Magmatic Sill in the BasqueCantabrian Basin, Western Pyrenees. Organic Geochemistry, 69, 26-35.

Alberdi-Genolet, M., Cavallaro, A., Hernandez, N., Crosta, D. \& Martinez, L. (2013) Magmatic Events and Sour Crude Oils in the Malargüe Area of the Neuquén Basin, Argentina. Marine and Petroleum Geology, 43, 48-62.

ANNEN, C. (2017) Factors Affecting the Thickness of Thermal Aureoles. Frontiers in Earth Science, 5.

This article is protected by copyright. All rights reserved. 
ANTUn, P. (1967) Sedimentary Pyrite and Its Metamorphism in the Oslo Region. Norsk Geologisk Tidsskrift, 47, 211-235.

BeRMúdeZ, A. \& DelPINO, D.H. (2008) Concentric and Radial Joint Systems within Basic Sills and Their Associated Porosity Enhancement, Neuquén Basin, Argentina. Geological Society, London, Special Publications, 302, 185-198.

BRISSÓN, I. \& VEIGA, R. (1998) La Estratigrafía Y Estructura De La Cuenca Neuquina. Gira de campo: Buenos Aires, Repsol YPF,(unpublished report).

BRUNe, S., WILLIAMS, S.E. \& MülLER, R.D. (2017) Potential Links between Continental Rifting, Co 2 Degassing and Climate Change through Time. Nature Geoscience, 10, 941.

CARTWRIGHT, J., HUUSE, M. \& APLIN, A. (2007) Seal Bypass Systems. AAPG bulletin, 91, 1141-1166.

ClaVIeR, C., HeIM, A. \& SCALA, C. (1976). Effect of Pyrite on Resistivity and Other Logging Measurements. SPWLA 17th Annual Logging Symposium, Society of Petrophysicists and Well-Log Analysts.

Cobbold, P., Diraison, M. \& Rossello, E. (1999) Bitumen Veins and Eocene Transpression, Neuquén Basin, Argentina. Tectonophysics, 314, 423-442.

Cobbold, P. \& Rossello, E. (2003) Aptian to Recent Compressional Deformation, Foothills of the Neuquén Basin, Argentina. Marine and Petroleum Geology, 20, 429-443.

Combina, A.M. \& NuLLo, F. (2011) Ciclos Tectónicos, Volcánicos Y Sedimentarios Del Cenozoico Del Sur De Mendoza-Argentina ( $35^{\circ}-37^{\circ} \mathrm{S}$ Y $\left.69^{\circ} 30^{\prime} \mathrm{w}\right)$. Andean geology, 38, 198-218.

COOPER, J.R., CRELLING, J.C., RIMMER, S.M. \& WHITTINGTON, A.G. (2007) Coal Metamorphism by Igneous Intrusion in the Raton Basin, Co and Nm: Implications for Generation of Volatiles. International Journal of Coal Geology, 71, 15-27.

Corseri, R., Senger, K., Selway, K., Abdelmalak, M.M., Planke, S. \& Jerram, D.A. (2017) Magnetotelluric Evidence for Massive Sulphide Mineralization in Intruded Sediments of the Outer Vøring Basin, Mid-Norway. Tectonophysics, 706, 196-205.

Courtillot, V.E. \& Renne, P.R. (2003) On the Ages of Flood Basalt Events. Comptes Rendus Geoscience, 335, 113-140.

Delaney, P.T., Pollard, D.D., ZIONY, J.I. \& MCKeE, E.H. (1986) Field Relations between Dikes and Joints: Emplacement Processes and Paleostress Analysis. Journal of Geophysical Research: Solid Earth, 91, 4920-4938.

DeLPINO, D.H. \& BERMÚDEZ, A.M. (2009) Petroleum Systems Including Unconventional Reservoirs in Intrusive Igneous Rocks (Sills and Laccoliths). The Leading Edge, 28, 804-811.

Dow, W.G. (1977) Kerogen Studies and Geological Interpretations. Journal of geochemical exploration, 7, 79-99.

EsPitalie, J., Deroo, G. \& Marquis, F. (1985) La Pyrolyse Rock-Eval Et Ses Applications. Deuxième Partie. Revue de I'Institut français du Pétrole, 40, 755-784.

FJeldskaAr, W., Helset, H., Johansen, H., Grunnaleite, I. \& HoRstad, I. (2008) Thermal Modelling of Magmatic Intrusions in the Gjallar Ridge, Norwegian Sea: Implications for Vitrinite Reflectance and Hydrocarbon Maturation. Basin Research, 20, 143-159.

GALLAND, O. (2012) Experimental Modelling of Ground Deformation Associated with Shallow Magma Intrusions. Earth and Planetary Science Letters, 317, 145-156.

Galland, O., Bertelsen, H., Eide, C., Guldstrand, F., Haug, Ø., Leanza, H.A., Mair, K., Palma, O., Planke, S. \& RABBEL, O. (2018) Storage and Transport of Magma in the Layered Crust-Formation of Sills and Related Flat-Lying Intrusions. In: Volcanic and Igneous Plumbing Systems (Ed. by, 113-138. Elsevier.

GANINO, C. \& ARNDT, N.T. (2009) Climate Changes Caused by Degassing of Sediments During the Emplacement of Large Igneous Provinces. Geology, 37, 323-326.

GILLETT, S.L. (2003) Paleomagnetism of the Notch Peak Contact Metamorphic Aureole, Revisited: Pyrrhotite from Magnetite+ Pyrite under Submetamorphic Conditions. Journal of Geophysical Research: Solid Earth, 108.

GUDMUNDSSON, A. \& LøTVEIT, I.F. (2014) Sills as Fractured Hydrocarbon Reservoirs: Examples and

This article is protected by copyright. All rights reserved. 
Models. Geological Society, London, Special Publications, 374, 251-271.

HANSEN, D.M. \& CARTWRIGHT, J. (2006) The Three-Dimensional Geometry and Growth of Forced Folds above Saucer-Shaped Igneous Sills. Journal of Structural Geology, 28, 1520-1535.

HORTON, B.K., FUENTES, F., BOLL, A., STARCK, D., RAMIREZ, S.G. \& STOCKLI, D.F. (2016) Andean Stratigraphic Record of the Transition from Backarc Extension to Orogenic Shortening: A Case Study from the Northern Neuquén Basin, Argentina. Journal of South American Earth Sciences, 71, 17-40.

Howell, J.A., SChWARZ, E., SPAlletTI, L.A. \& VeigA, G.D. (2005) The Neuquén Basin: An Overview. Geological Society, London, Special Publications, 252, 1-14.

Hughes, H.S., McDonald, I., BOYCE, A.J., Holwell, D.A. \& KeRR, A.C. (2016) Sulphide Sinking in Magma Conduits: Evidence from Mafic-Ultramafic Plugs on Rum and the Wider North Atlantic Igneous Province. Journal of Petrology, 57, 383-416.

HUNT, J.M. (1996) Petroleum Geochemistry and Geology. WH Freeman New York.

IYER, K., RÜPKE, L. \& GALERNE, C.Y. (2013) Modeling Fluid Flow in Sedimentary Basins with Sill Intrusions: Implications for Hydrothermal Venting and Climate Change. Geochemistry, Geophysics, Geosystems, 14, 5244-5262.

IYER, K., SCHMID, D.W., PLANKE, S. \& MILlETT, J. (2017) Modelling Hydrothermal Venting in Volcanic Sedimentary Basins: Impact on Hydrocarbon Maturation and Paleoclimate. Earth and Planetary Science Letters, 467, 30-42.

JAmtVeit, B., SVenSEN, H., PodladChikov, Y.Y. \& Planke, S. (2004) Hydrothermal Vent Complexes Associated with Sill Intrusions in Sedimentary Basins. Physical geology of high-level magmatic systems, 234, 233-241.

Kozlowski, E., MANCEDA, R., RAMOS, V. \& RAMOS, V. (1993). Estructura. Geología y Recursos Naturales de Mendoza: Relatorio del 12 Congreso Geológico Argentino y 2 Congreso de Exploración de Hidrocarburos, I (18).

Krumbholz, M., Hieronymus, C.F., Burchardt, S., Troll, V.R., TANner, D.C. \& Friese, N. (2014) WeibullDistributed Dyke Thickness Reflects Probabilistic Character of Host-Rock Strength. Nature communications, 5, 3272.

LehmanN, J., ARNDT, N., WindleY, B., ZHOU, M.-F., WANG, C.Y. \& HARRIS, C. (2007) Field Relationships and Geochemical Constraints on the Emplacement of the Jinchuan Intrusion and Its Ni-CuPge Sulfide Deposit, Gansu, China. Economic Geology, 102, 75-94.

MAgee, C., BAstow, I.D., VAN WYK de VRIES, B., Jackson, C.A.-L., Hetherington, R., HAgos, M. \& HoggetT, M. (2017) Structure and Dynamics of Surface Uplift Induced by Incremental Sill Emplacement. Geology, 45, 431-434.

MANCEDA, R. \& FIGUEROA, D. (1995) Inversion of the Mesozoic Neuquén Rift in the Malargüe Fold and Thrust Belt, Mendoza, Argentina.

MAzURov, M., GrishinA, S., Titov, A. \& ShiKHovA, A. (2018) Evolution of Ore-Forming Metasomatic Processes at Large Skarn Iron Deposits Related to the Traps of the Siberian Platform. Petrology, 26, 265-279.

MÉRIAUX, C., LISTER, J.R., LYAKHOVSKY, V. \& AGNON, A. (1999) Dyke Propagation with Distributed Damage of the Host Rock. Earth and Planetary Science Letters, 165, 177-185.

MonReal, F.R., VILlar, H., BAUdino, R., Delpino, D. \& ZenCich, S. (2009) Modeling an Atypical Petroleum System: A Case Study of Hydrocarbon Generation, Migration and Accumulation Related to Igneous Intrusions in the Neuquen Basin, Argentina. Marine and Petroleum Geology, 26, 590-605.

MUIRHEAD, J.D., AIROLDI, G., ROWLAND, J.V. \& WHITE, J.D. (2012) Interconnected Sills and Inclined Sheet Intrusions Control Shallow Magma Transport in the Ferrar Large Igneous Province, Antarctica. Bulletin, 124, 162-180.

OrChUela, I., LARA, M.E. \& SUAREZ, M. (2003). Productive Large Scale Folding Associated with Igneous Intrusions: El Trapial Field, Neuquen Basin, Argentina. 2003 AAPG International Conference \& Exhibition Technical Program.

PANG, K.-N., ZHOU, M.-F., QI, L., CHUnG, S.-L., CHU, C.-H. \& LeE, H.-Y. (2013) Petrology and Geochemistry

This article is protected by copyright. All rights reserved. 
at the Lower Zone-Middle Zone Transition of the Panzhihua Intrusion, Sw China: Implications for Differentiation and Oxide Ore Genesis. Geoscience Frontiers, 4, 517-533.

PARASNIS, D. (1956) The Electrical Resistivity of Some Sulphide and Oxide Minerals and Their Ores. Geophysical Prospecting, 4, 249-278.

Polozov, A.G., SVensen, H.H., Planke, S., Grishina, S.N., Fristad, K.E. \& Jerram, D.A. (2016) The Basalt Pipes of the Tunguska Basin (Siberia, Russia): High Temperature Processes and Volatile Degassing into the End-Permian Atmosphere. Palaeogeography, Palaeoclimatology, Palaeoecology, 441, 51-64.

Polteau, S., Hendriks, B.W., Planke, S., Ganerød, M., Corfu, F., Faleide, J.I., Midtkandal, I., Svensen, H.S. \& MYKLEBUST, R. (2016) The Early Cretaceous Barents Sea Sill Complex: Distribution, 40ar/39ar Geochronology, and Implications for Carbon Gas Formation. Palaeogeography, Palaeoclimatology, Palaeoecology, 441, 83-95.

Rabbel, O., Galland, O., Mair, K., Lecomte, I., Senger, K., SPacAPan, J.B. \& Manceda, R. (2018) From Field Analogues to Realistic Seismic Modelling: A Case Study of an Oil-Producing Andesitic Sill Complex in the Neuquén Basin, Argentina. Journal of the Geological Society, jgs2017-2116.

Ramos, V.A., Vujovich, G., Martino, R. \& OtAMEndI, J. (2010) Pampia: A Large Cratonic Block Missing in the Rodinia Supercontinent. Journal of Geodynamics, 50, 243-255.

RASMUSSEN, B. \& FLETCHER, I.R. (2002) Indirect Dating of Mafic Intrusions by Shrimp U-Pb Analysis of Monazite in Contact Metamorphosed Shale: An Example from the Palaeoproterozoic Capricorn Orogen, Western Australia. Earth and Planetary Science Letters, 197, 287-299.

RAteAU, R., SCHOFIELD, N. \& SMITH, M. (2013) The Potential Role of Igneous Intrusions on Hydrocarbon Migration, West of Shetland. Petroleum Geoscience, 19, 259-272.

SchIUMA, M.F. (1994) Intrusivos Del Valle Del Río Grande, Provincia De Mendoza, Su Importancia Como Productores De Hidrocarburos, Facultad de Ciencias Naturales y Museo. 350, 41-63

Schmiedel, T., KJoberg, S., Planke, S., Magee, C., Galland, O., SChofield, N., Jackson, C.A.-L. \& Jerram, D.A. (2017) Mechanisms of Overburden Deformation Associated with the Emplacement of the Tulipan Sill, Mid-Norwegian Margin. Interpretation, 5, SK23-SK38.

Schofield, N., Holford, S., Millett, J., Brown, D., Jolley, D., PASSey, S.R., Muirhead, D., Grove, C., MAgeE, C. \& MurRAY, J. (2017) Regional Magma Plumbing and Emplacement Mechanisms of the Faroe - Shetland Sill Complex: Implications for Magma Transport and Petroleum Systems within Sedimentary Basins. Basin Research, 29, 41-63.

Schofield, N., Jerram, D.A., Holford, S., ArCher, S., Mark, N., Hartley, A., Howell, J., Muirhead, D., Green, P. \& Hutton, D. (2018) Sills in Sedimentary Basins and Petroleum Systems. In: Physical Geology of Shallow Magmatic Systems (Ed. by, 273-294. Springer.

SCHOField, N.J., BROWN, D.J., MAgeE, C. \& SteVEnSON, C.T. (2012) Sill Morphology and Comparison of Brittle and Non-Brittle Emplacement Mechanisms. Journal of the Geological Society, 169, 127-141.

Senger, K., Buckley, S.J., Chevallier, L., Fagereng, Å., Galland, O., Kurz, T.H., Ogata, K., Planke, S. \& TVERANGER, J. (2015) Fracturing of Doleritic Intrusions and Associated Contact Zones: Implications for Fluid Flow in Volcanic Basins. Journal of African Earth Sciences, 102, 70-85.

Senger, K., Millett, J., Planke, S., Ogata, K., Eide, C.H., Festøy, M., Galland, O. \& Jerram, D.A. (2017) Effects of Igneous Intrusions on the Petroleum System: A Review. First Break, 35, 47-56.

Spacapan, J., Palma, O., Galland, O., Manceda, R., Rocha, E., D'Odorico, A. \& Leanza, H. (2018) Thermal Impact of Igneous Sill-Complexes on Organic-Rich Formations and Implications for Petroleum Systems: A Case Study in the Northern Neuquén Basin, Argentina. Marine and Petroleum Geology.

SpaCAPAN, J.B., GAlLAND, O., LeAnZA, H.A. \& Planke, S. (2017) Igneous Sill and Finger Emplacement Mechanism in Shale-Dominated Formations: A Field Study at Cuesta Del Chihuido, Neuquén Basin, Argentina. Journal of the Geological Society, 174, 422-433.

SVensen, H., Planke, S., Malthe-Sørenssen, A., JamtVeit, B., Myklebust, R., Eidem, T.R. \& Rey, S.S. (2004) Release of Methane from a Volcanic Basin as a Mechanism for Initial Eocene Global Warming.

This article is protected by copyright. All rights reserved. 
Nature, 429, 542-545.

Svensen, H., Planke, S., Chevallier, L., Malthe-Sørenssen, A., Corfu, F. \& JamtVeit, B. (2007) Hydrothermal Venting of Greenhouse Gases Triggering Early Jurassic Global Warming. Earth and Planetary Science Letters, 256, 554-566.

SVensen, H., Planke, S., Polozov, A.G., Schmidbauer, N., Corfu, F., Podladchikov, Y.Y. \& JamtVeit, B. (2009) Siberian Gas Venting and the End-Permian Environmental Crisis. Earth and Planetary Science Letters, 277, 490-500.

SVENSEN, H. \& JAMTVEIT, B. (2010) Metamorphic Fluids and Global Environmental Changes. Elements, 6, 179-182.

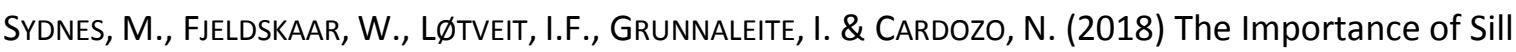
Thickness and Timing of Sill Emplacement on Hydrocarbon Maturation. Marine and Petroleum Geology, 89, 500-514.

SYLWAN, C. (2014). Source Rock Properties of Vaca Muerta Formation, Neuquina Basin, Argentina. Simposio de Recursos No Convencionales. IX Congreso Argentino de Exploración y Desarrollo de Hidrocarburos. IAPG. Mendoza, Argentina.

TOWNSEnd, M., Pollard, D.D., Johnson, K. \& CULHA, C. (2015) Jointing around Magmatic Dikes as a Precursor to the Development of Volcanic Plugs. Bulletin of Volcanology, 77, 92.

Vergani, G.D., TANKARD, A.J., BelotTI, H.J. \& Welsink, H.J. (1995) Tectonic Evolution and Paleogeography of the Neuquén Basin, Argentina.

WAPLES, D. \& ToBeY, M.H. (2015). Like Space and Time, Transformation Ratio Is Curved. AAPG Annual Convention and Exhibition.

WitTE, J., Bonora, M., CARBone, C. \& ONCKEN, O. (2012) Fracture Evolution in Oil-Producing Sills of the Rio Grande Valley, Northern Neuquén Basin, Argentina. AAPG bulletin, 96, 1253-1277.

ZHANG, W., WANG, Q., YE, J. \& ZHOU, J. (2017) Fracture Development and Fluid Pathways in Shales During Granite Intrusion. International Journal of Coal Geology, 183, 25-37.

ZierenBerG, R.A., KoskI, R.A., MORTON, J.L. \& BOUSE, R.M. (1993) Genesis of Massive Sulfide Deposits on a Sediment-Covered Spreading Center, Escanaba Trough, Southern Gorda Ridge. Economic Geology, 88, 2069-2098.

This article is protected by copyright. All rights reserved. 


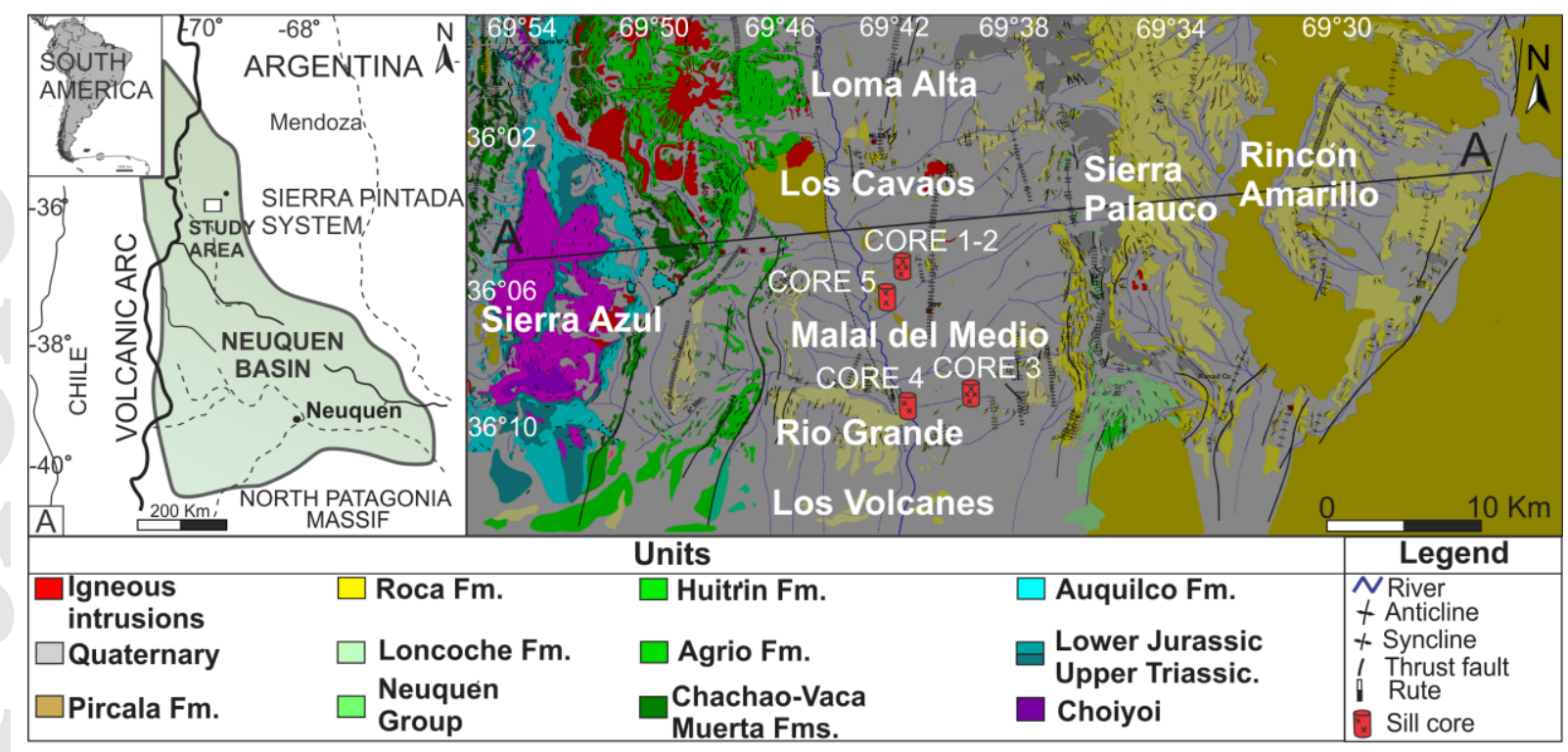

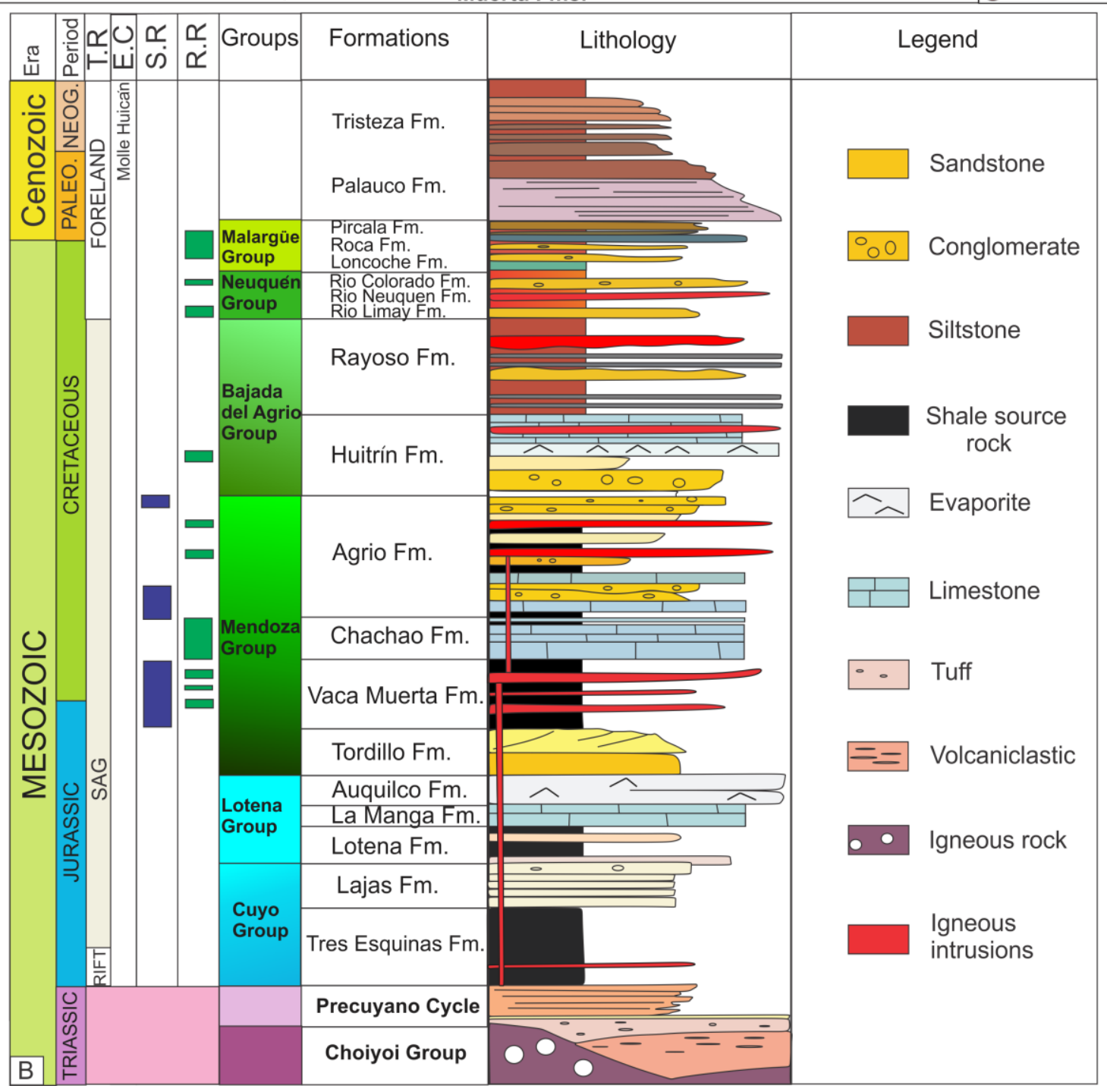

This article is protected by copyright. All rights reserved. 

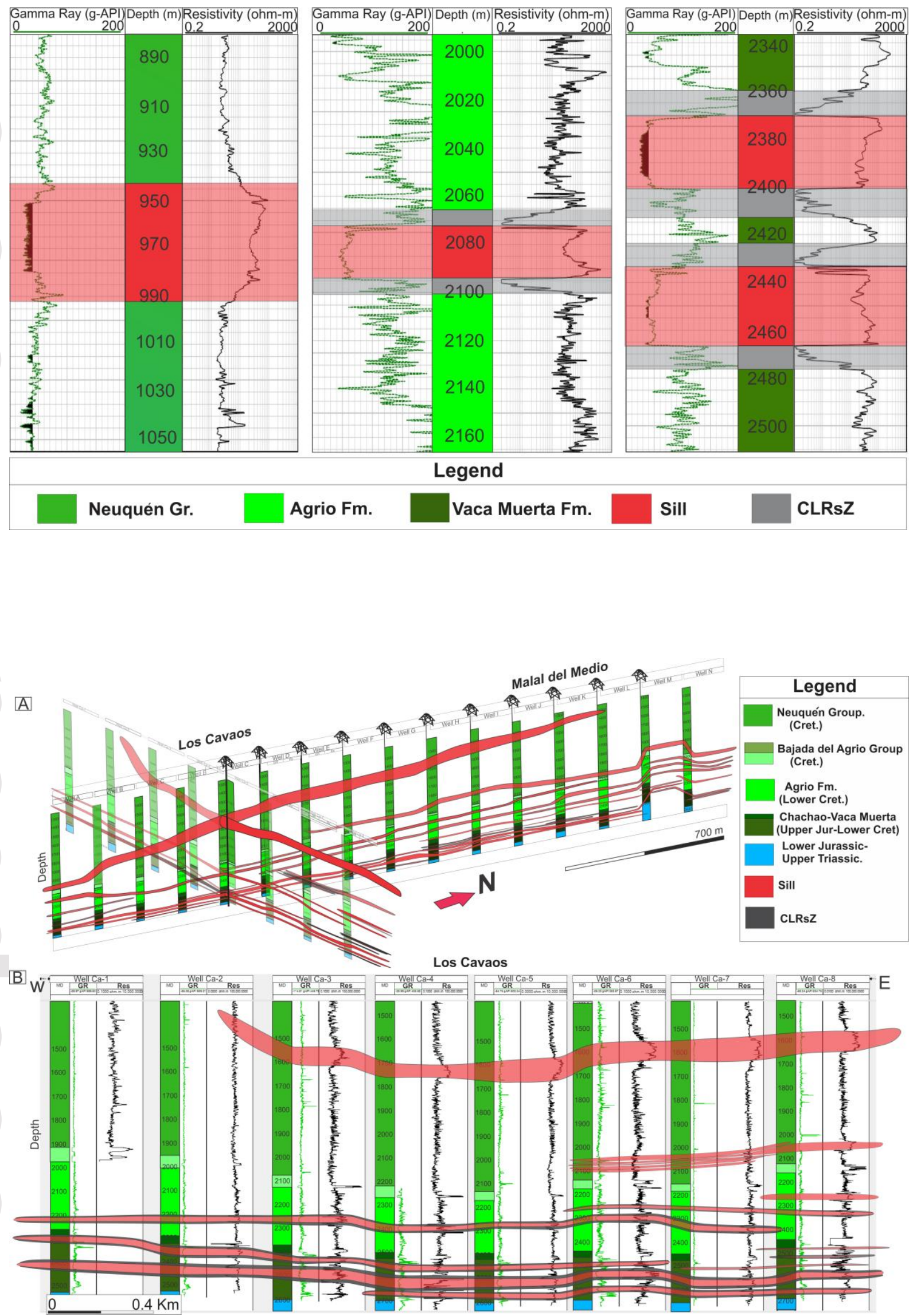

This article is protected by copyright. All rights reserved. 

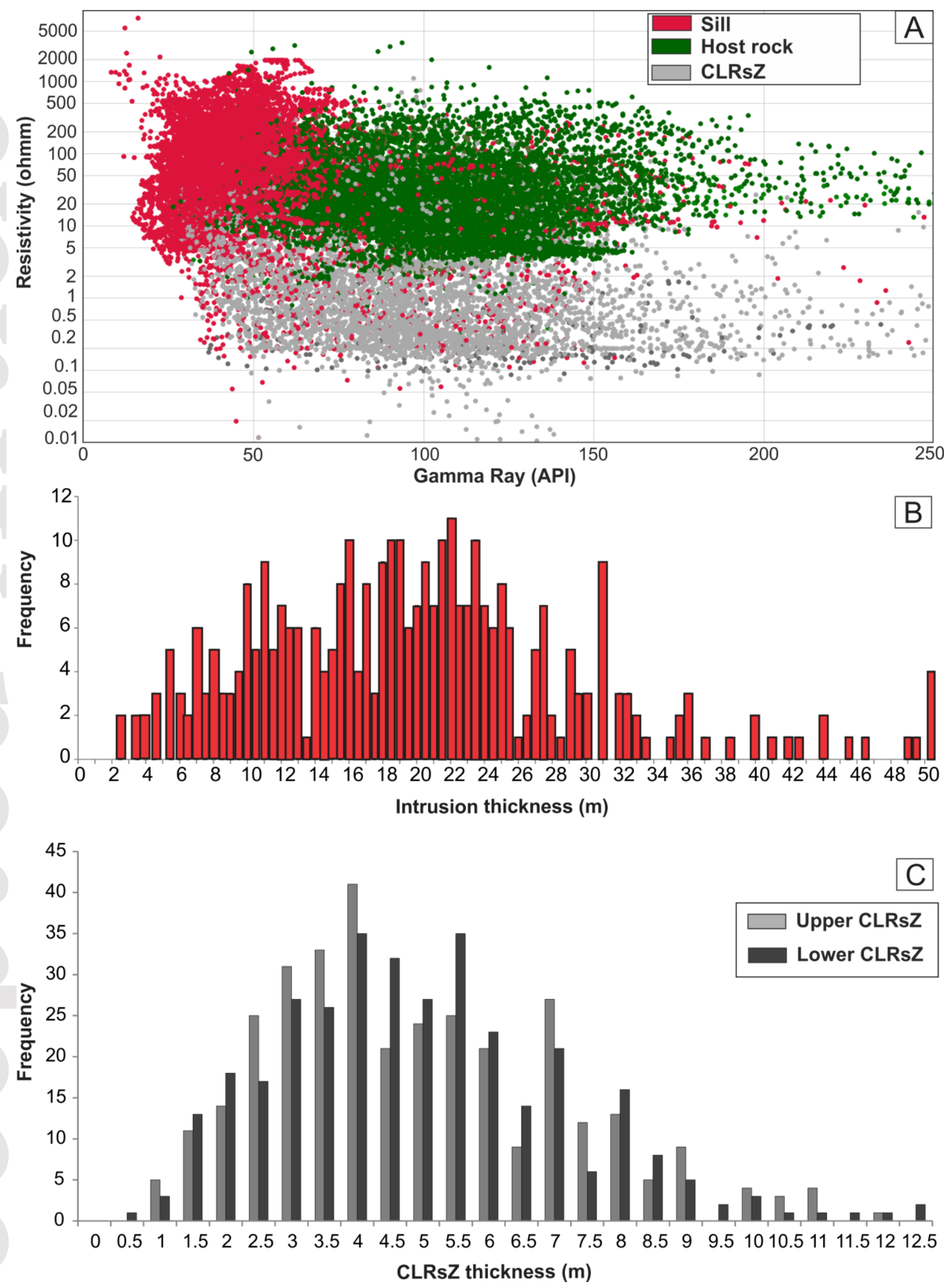

This article is protected by copyright. All rights reserved. 

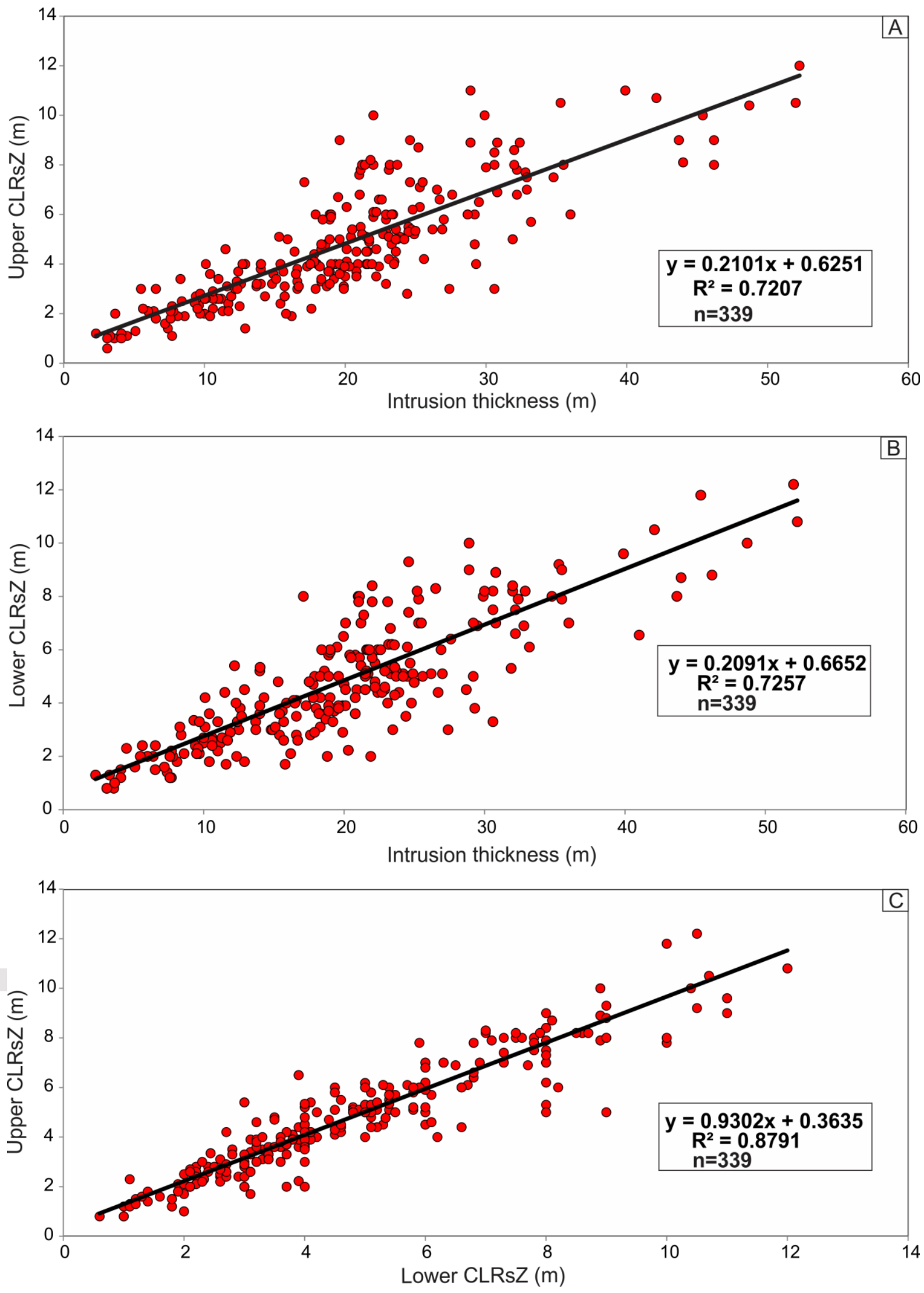

This article is protected by copyright. All rights reserved. 

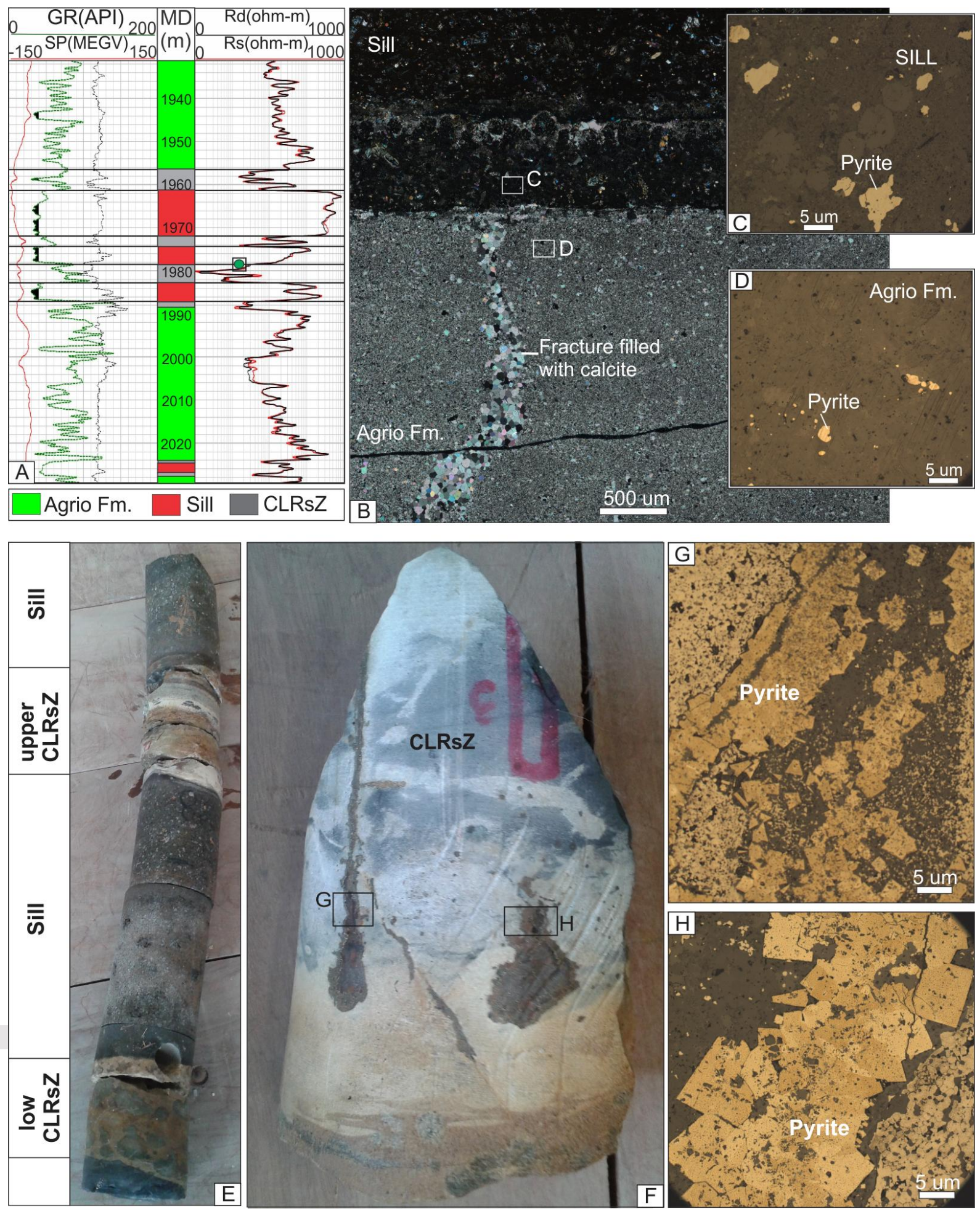

This article is protected by copyright. All rights reserved. 

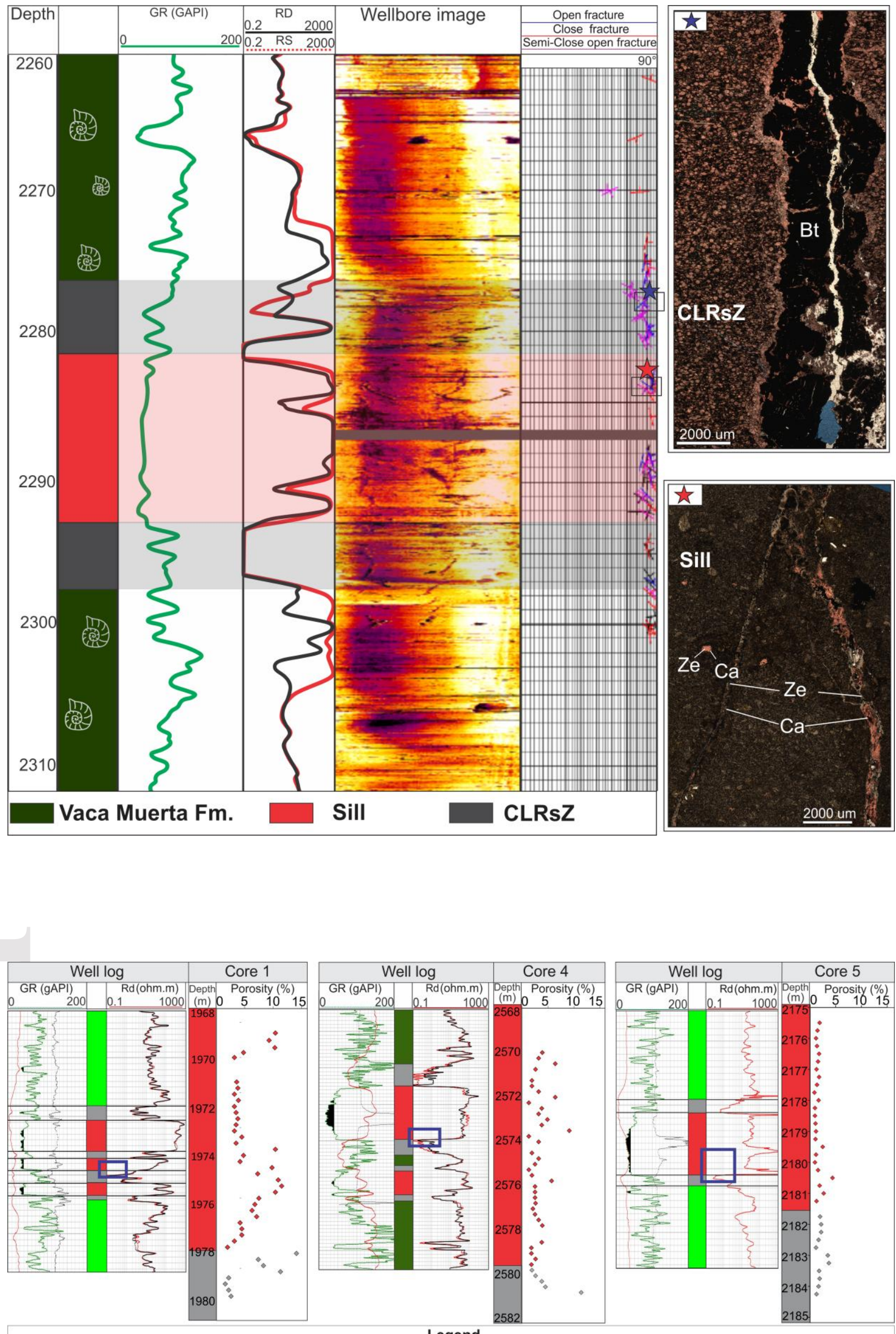

Neuqueń Gr.

Agrio Fm.

Vaca Muerta Fm.

Sill

CLRsZ

This article is protected by copyright. All rights reserved. 


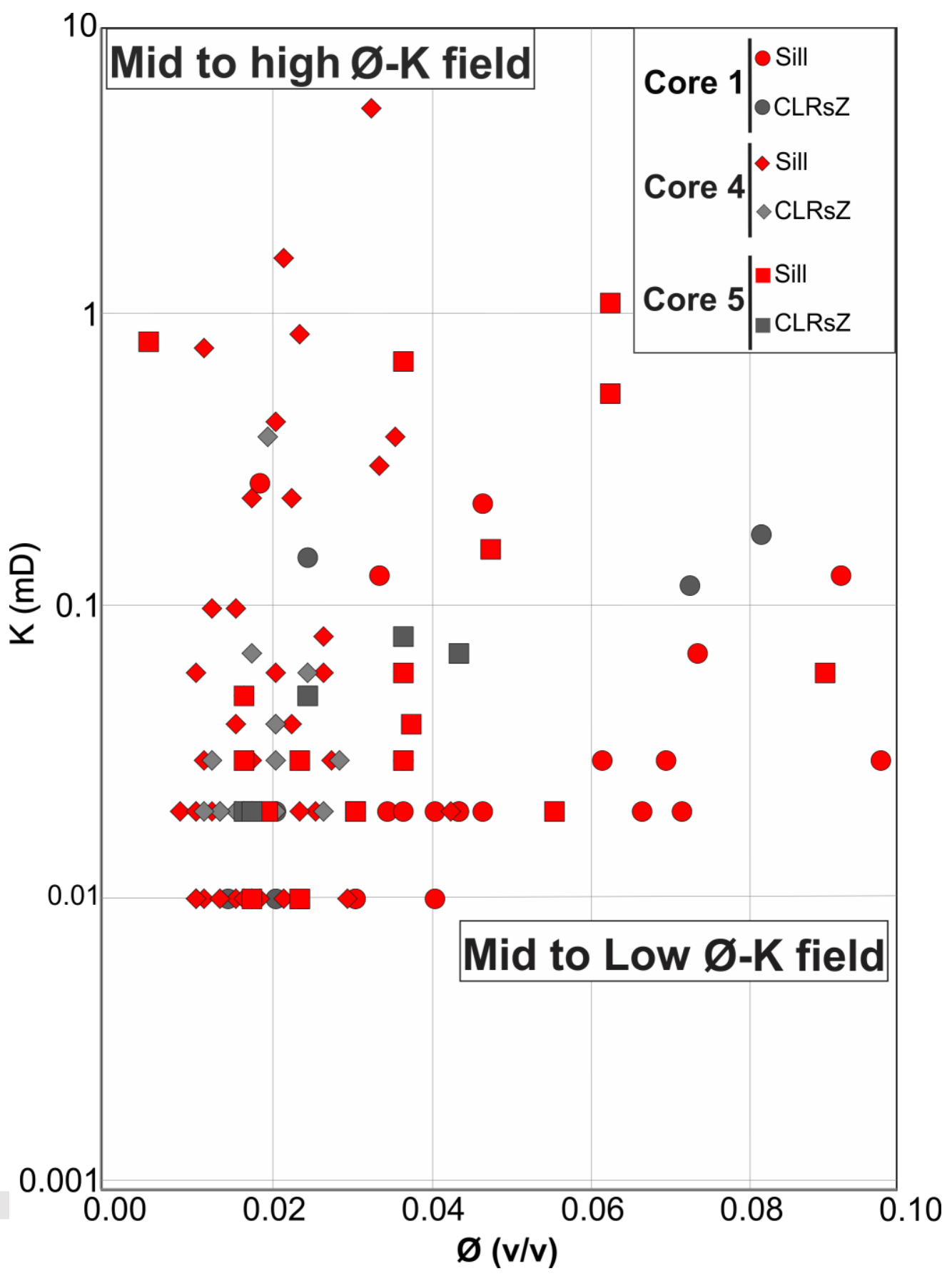

This article is protected by copyright. All rights reserved. 


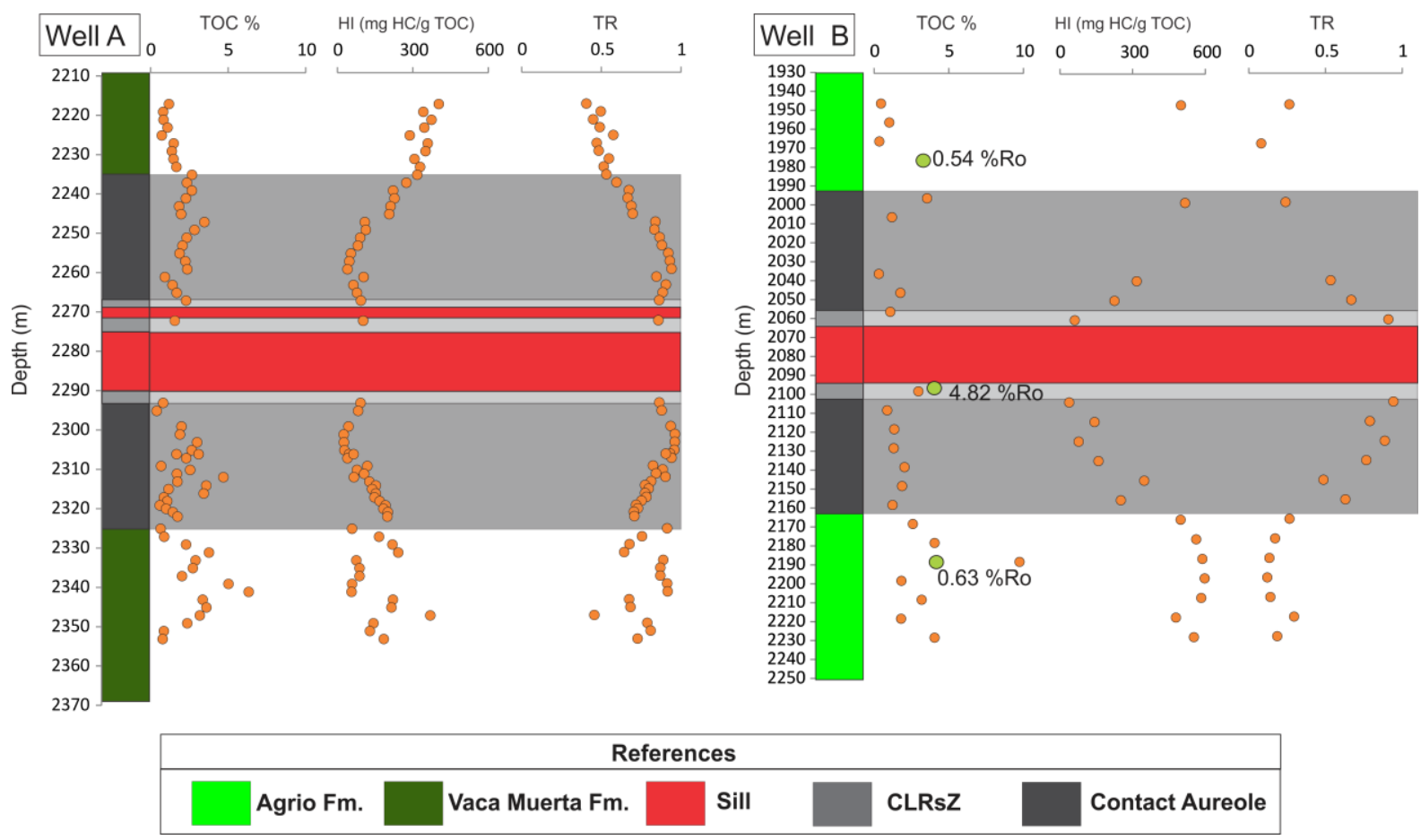

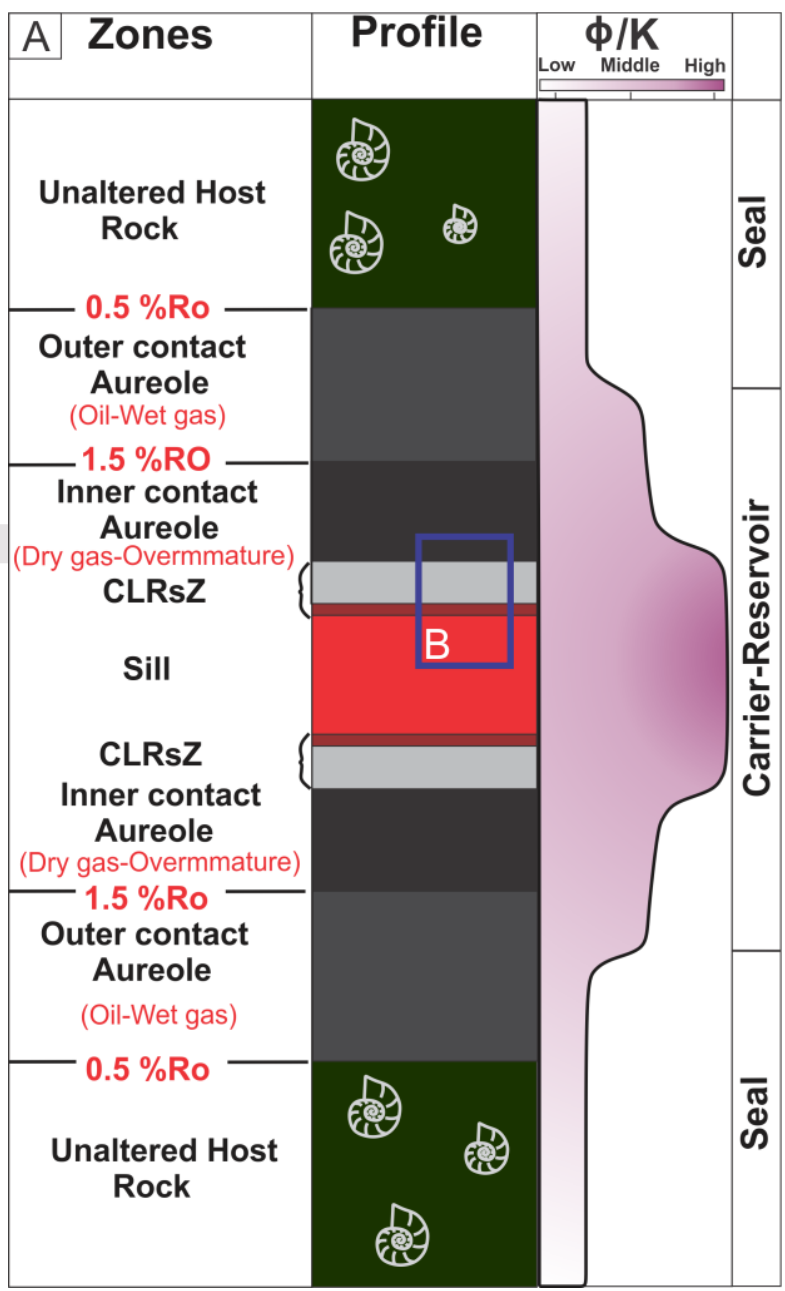

\section{B $\quad$ Detailed Profile of CLRsZ}

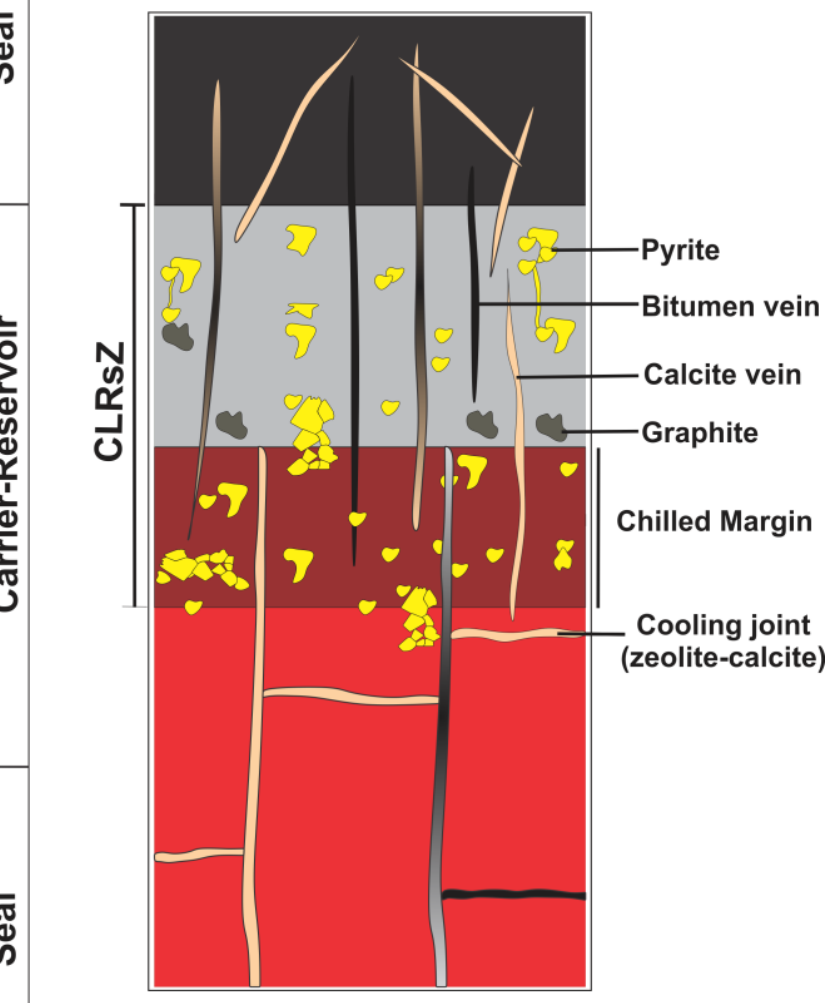

This article is protected by copyright. All rights reserved. 

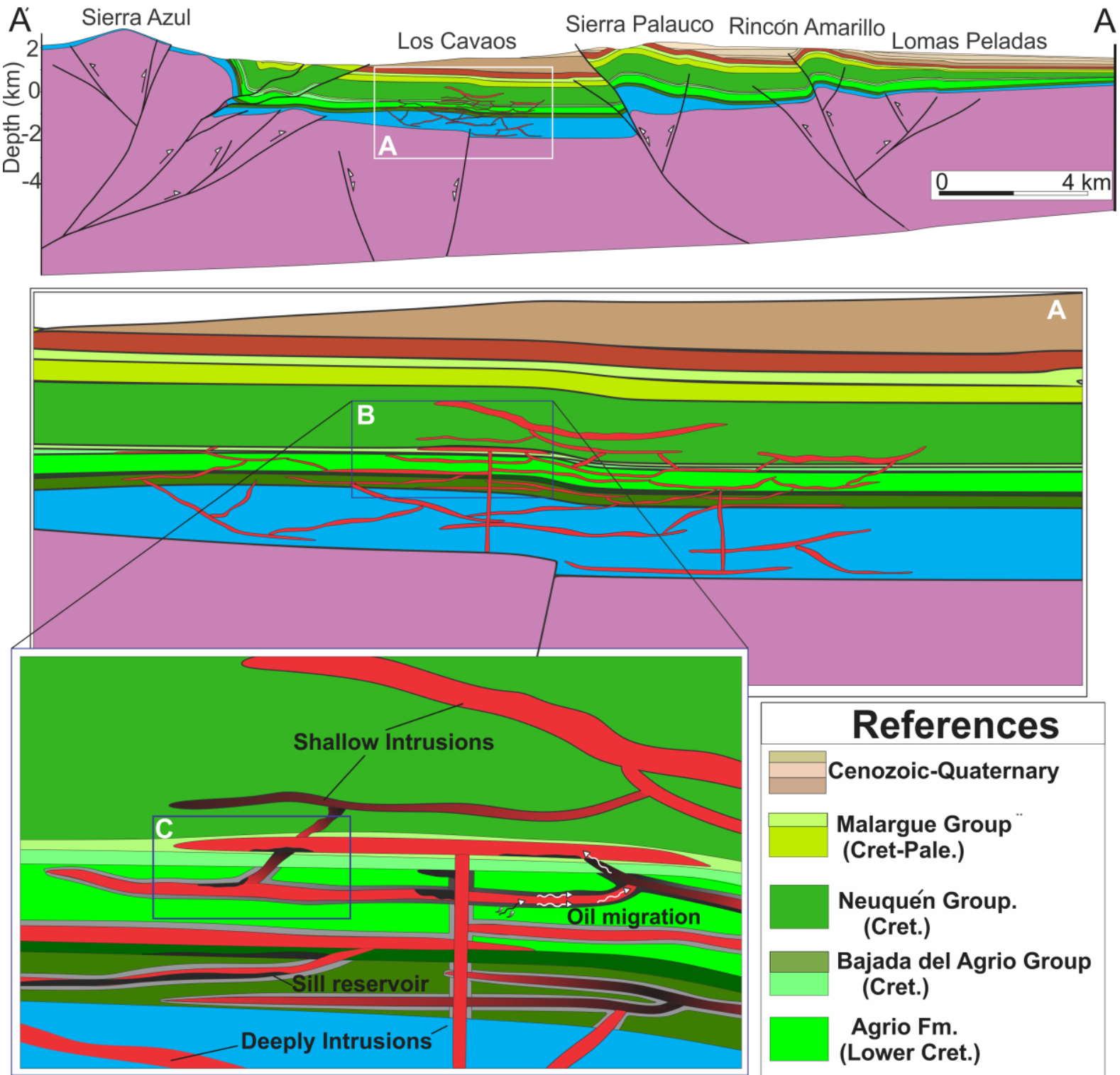

References

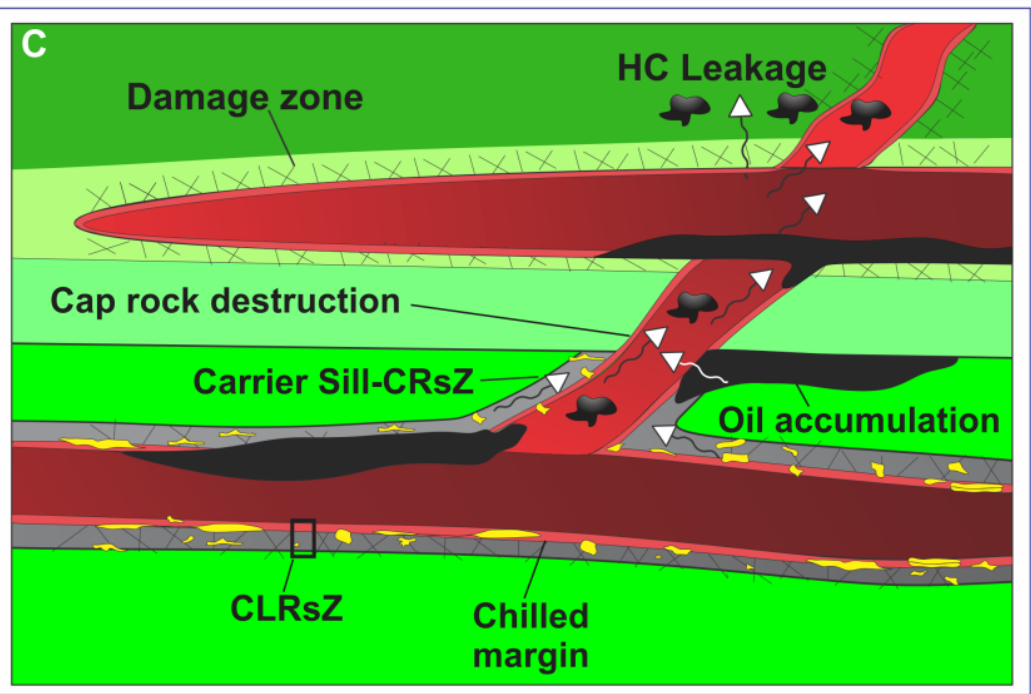

Chachao-Vaca Muerta (Upper Jur-Lower Cret)

Lower Jurassic-

Upper Triassic.

Choiyoi Group

Sill Reservoir-Carrier

CLRsZ Reservoir-Carrier

Massive sulphide

Oil Migration

This article is protected by copyright. All rights reserved. 